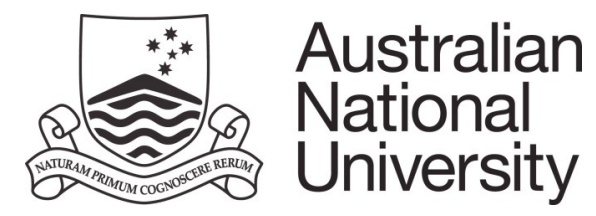

AUSTRALIA-JAPAN RESEARCH CENTRE

ANU COLLEGE OF ASIA \& THE PACIFIC

CRAWFORD SCHOOL OF PUBLIC POLICY

\title{
NONPERFORMING LOANS AND PUBLIC ASSET MANAGEMENT COMPANIES IN MALAYSIA AND THAILAND
}

Masahiro Inoguchi

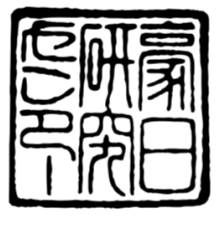

ASIA PACIFIC ECONOMIC PAPERS

No. 398, 2012 



\section{ASIA PACIFIC ECONOMIC PAPER NO. 398}

2012

\section{NONPERFORMING LOANS AND PUBLIC ASSET MANAGEMENT COMPANIES IN MALAYSIA AND THAILAND}

Masahiro Inoguchi

AUSTRALIA-JAPAN RESEARCH CENTRE CRAWFORD SCHOOL OF PUBLIC POLICY ANU COLLEGE OF ASIA AND THE PACIFIC 


\section{(C) Masahiro Inoguchi, 2012}

This work is copyright. Apart from those uses which may be permitted under the Copyright Act 1968 as amended, no part may be reproduced by any process without written permission.

Asia Pacific Economic Papers are published under the direction of the Editorial Committee of the Australia-Japan Research Centre (AJRC). Members of the Editorial Committee are:

\section{Professor Jenny Corbett}

Executive Director

Australia-Japan Research Centre

The Australian National University, Canberra

\section{Professor Ippei Fujiwara}

Assistant Professor of Economics

Australia-Japan Research Centre

The Australian National University, Canberra

\section{Dr Kazuki Onji}

Crawford School of Public Policy

The Australian National University, Canberra

Papers submitted for publication in this series are subject to double-blind external review by two referees. The views expressed in APEPs are those of the individual authors and do not represent the views of the Australia-Japan Research Centre, the Crawford School, or the institutions to which authors are attached.

The Australia-Japan Research Centre is part of the Crawford School of Public Policy, The Australian National University, Canberra.

\section{ISSN 07288409}

\section{ISBN 978-0-86413-352-6}

\section{Australia-Japan Research Centre}

Crawford School of Public Policy

The Australian National University

Canberra ACT 0200

Telephone: (61 2) 61250168

Facsimile: (61 2) 61258448

E-mail: ajrc@anu.edu.au

URL: http://www.crawford.anu.edu.au 


\title{
NONPERFORMING LOANS AND PUBLIC ASSET MANAGEMENT COMPANIES IN MALAYSIA AND THAILAND*
}

\author{
Masahiro Inoguchi §
}

\begin{abstract}
This paper explores the factors which eliminated the nonperforming loan (NPL) problem in Malaysia and Thailand following the 1997 Asian Financial Crisis. The number of NPLs which expanded in the aftermath of the crisis, has since declined in most Southeast Asian countries. Although previous studies have explored the causes of the increase in NPL numbers, few have analysed the factors that contributed to the reduction in their number in Asia. In Malaysia and Thailand, authorities put in place a number of measures to manage NPLs. As a vehicle to acquire NPLs from banks, Malaysia established the Pengurusan Danaharta Nasional Berhad (Danaharta) in 1998, while Thailand established the Thai Asset Management Corporation (TAMC) in 2001. We analyse whether the characteristic features of banks, improvements in macroeconomic conditions, and facilities for purchasing loans caused a reduction in the number of NPLs in Malaysia and Thailand. The results suggest that selling loans to a public asset management company was effective in reducing the number of NPLs in Thailand. However, while macroeconomic conditions influenced the decline in NPL ratios in Thailand, in Malaysia, good performing commercial banks and large commercial and investment banks generally had smaller NPL ratios throughout and following the crisis.
\end{abstract}

Keywords: Nonperforming loans; macroeconomic conditions; bank characteristics; public asset management companies; selling loans; Malayasia and Thailand JEL Classification: G21; 016

* The author gratefully acknowledges helpful comments and suggestions by Jenny Corbett, John Tang, Timo Henckel, Shigeyuki Abe, Fumiharu Mieno, Daiji Kawaguchi, Hiroshi Gunji, Junji Yano, anonymous referees, seminar participants at Doshisha University in 2010, Hitotsubashi University in 2011, and the Australian National University in 2011, and delegates at the 2010 meeting of the Japan Society of Monetary Economics. All errors in this paper are solely mine. This research was supported in part by a Grant-in-Aid for Scientific Research for Young Scientists from the Japanese Ministry of Education, Science, Sports, and Culture.

$\S$ Masahiro Inoguchi, Kyoto Sangyo University . E: inoguchi@cc.kyoto-su.ac.jp 


\section{Introduction}

Since the 1997 Asian Financial Crisis, governmental authorities throughout Southeast Asia have continued to pursue reform of their banking systems. In Southeast Asia, a sound banking system is particularly important, because a significant number of companies rely heavily on bank loans for financing. Nonperforming loans (NPLs) in particular can become a major problem for a banking system, as evidenced in recent experiences around the world. One example is the substantial losses throughout the US banking sector which resulted from the decline in housing prices in the US, itself fueled by the large number of subprime mortgages and NPLs. The collapse of land prices in Japan in the 1990s, which escalated the number of NPLs via real estate collateral loans and provoked a banking system crisis, is another. Some Southeast Asian countries have experienced similar problems, notably after the 1997 Asian Financial Crisis, when the massive increase in NPLs wreaked havoc on the region's banking system. ${ }^{1}$ Consequently some banks faced bankruptcy, and the number of bank loans declined, causing macroeconomic conditions to worsen significantly.

The governments of the Asian countries affected by the 1997 crisis have sought to rebuild their banking systems by restructuring and consolidating domestic banks. In addition, government authorities attempted to eliminate NPLs by purchasing them from banks. ${ }^{2}$ These measures may have had contributed to the reduction in number of NPLs. ${ }^{3}$ Since 1999, macroeconomic conditions have improved, and NPLs have gradually declined in most Southeast Asian countries. This paper explores whether the characteristic features of banks, the purchase of loans by NPL management facilities, and improvements in macroeconomic conditions caused the reduction in NPLs in both Malaysia and Thailand.

It is important to discuss the policies that eliminated NPLs in Southeast Asia because this problem may also arise in other emerging economies. Although many studies have highlighted how NPLs increased in the first instance and have

\footnotetext{
${ }^{1}$ Ito (1999) noted that real estate prices increased when the economy expanded in the 1990s before the 1997 Asian crisis.

${ }^{2}$ Fung et al. (2004) compared government-established and government-owned asset management companies in East Asia since the late 1990s. They argue that these asset management companies have many common characteristics. Bonin and Huang (2001) discussed the importance of the establishment of asset management companies in China.

${ }^{3}$ Although selling NPLs should reduce the amount of NPLs in each bank, NPLs could increase when banks subsequently increase loans to less creditworthy companies. 
discussed solutions to the problem, few have analysed why NPLs declined in Asia and in particular the factors that contributed to the reduction of NPLs in Southeast Asian countries. In Japan, Hosono (2010) has investigated factors which caused NPLs to decrease. In this study, Hosono (2010) looked at factors which increased the number of NPLs as explanatory variables in the regression, and showed that land prices were an important contributing factor in the decline of NPLs. In other work, Boudriga et al. (2009) employed aggregate banking, financial, economic, and legal environment data from a panel of 59 countries over the period 2002-06 and empirically analysed the cross-country determinants of nonperforming loans. This study suggested that higher capital adequacy ratios and prudent provisioning policies appeared to reduce the level of problem loans. ${ }^{4}$

Previous studies have discussed the incidence of and solutions for NPLs and some studies have described the processes of and factors influencing the NPL problem in Asia. For example, Ueda (2000) analysed the causes of NPLs in Japanese banks in the 1990s, including the role of real estate related loans, the influence of financial liberalisation, inefficient bank management, and moral hazards relating to certain safety nets. Hu et al. (2004) examined the influence of deregulation on the NPLs of a panel of Taiwanese commercial banks during the period 1996-99, identifying a relationship between the number of NPLs and the total loan amount (hereafter, the NPL ratio) and government shareholdings. This study concluded that as the percentage of government shareholdings in a bank increased, the NPL rate initially fell and then increased thereafter. Moreover, they found a negative correlation between bank size and the NPL ratio. ${ }^{5}$

The governments of Malaysia and Thailand undertook a number of measures to manage NPLs in their respective jurisdictions, although the periods of establishment differ. To acquire NPLs, Malaysia established the Pengurusan Danaharta Nasional Berhad (or Danaharta) as an asset management company in 1998, while Thailand founded the Thai Asset Management Corporation (TAMC) in 2001. ${ }^{6}$ The IMF (2004) suggests that one reason why Thailand instituted the

\footnotetext{
${ }^{4}$ Hasan and Wall (2004) analyzed the determining factors in loan loss reserves in the US, Canada, and Japan. Also in the US, Berger and De Young (1997) analytically explored the relationships between loan quality, cost efficiency, and bank capital. They suggested that cost efficiency was an important indicator of future problem loans and banks.

${ }^{5}$ Sinkey et al. (1991) analyzed the loan-loss factor and suggested that banks with adequate capital tended to have lower loss rates.

${ }^{6}$ In addition, after the Asian crisis, some banks in Malaysia and Thailand received capital
} 
restructuring of its banks' NPLs much later than in many other Asian countries was because of the relatively late establishment of an agency to acquire nonperforming assets. ${ }^{7}$ However, no studies have considered whether the establishment of these agencies was a more efficient solution to the problem of NPLs than simply waiting for an improvement in macroeconomic and/or bank conditions. ${ }^{8}$ Given that the Malaysian and Thai economies had recovered by 1999, this paper focuses on three factors relating to the decline of NPLs in these countries: namely, (i) the purchase of loans by facilities for managing nonperforming assets, (ii) the influence of bank characteristics, and (iii) macroeconomic indicators on the decline in NPL ratios in both countries. Following Ueda (2000) and Hosono (2010), we employ a panel regression analysis of domestic bank data to examine the factors affecting the decline in NPL ratios. ${ }^{9}$

The results suggest that the purchase of loans by public asset management companies was effective in stimulating a decline in the number of NPLs in Thailand. This implies that Thai banks could have reduced their NPLs sooner if the government had established TAMC earlier (that is, before 2001). In Malaysia, although banking loans and NPLs may have increased while Danaharta purchased loans, it is difficult to deny the influence of the selling of loans. While the improvement in macroeconomic conditions reduced NPL ratios in Thailand, this effect was especially clear in the period when TAMC did not buy NPLs from Thai commercial banks. By contrast, in Malaysia, large commercial and investment banks and good performing commercial banks had smaller NPL ratios.

\footnotetext{
injections.

${ }^{7}$ The IMF suggests that it is difficult to evaluate the progress of TAMC because of insufficient information disclosure, although they do concede that the notional statistics illustrate that TAMC played a progressive role in the restructuring process for nonperforming loans.

${ }^{8}$ Although Terada-Hagiwara and Pasadilla (2004) support the effectiveness of asset management companies in relation to the Thai NPL problem, they also examined whether asset management companies increased moral hazard in banks.

${ }^{9}$ Relocating NPLs to asset management facilities may potentially and efficiently reduce the stock of NPLs. However, the current paper analyzes only the effects of selling loans on the decline in the number of NPLs in each bank and does not consider the efficiency effects of the decline in the number of NPLs nationwide. Therefore, we do not include the impact of relocating NPLs to public facilities on the burden of the government sector and macroeconomic conditions.
} 
The remainder of the paper is as follows: Section 2 reviews developments in the restructuring of NPLs in the Malaysian and Thai banking sectors after the 1997 Asian financial crisis and explains the roles of Danaharta and TAMC. This section also describes the trends in the NPL ratio, land prices, and GDP growth in both countries. Section 3 discusses the hypotheses to be examined using panel data for domestic banks. Section 4 provides some concluding remarks.

\section{Nonperforming loans, asset management companies, and the macroeconomy}

\subsection{Banking sector reform and the role of Danaharta and TAMC}

In the aftermath of the Asian Crisis, authorities in crisis-affected countries attempted to address the problems of bank capitalization, governance, risk management, and operational inefficiencies. Another important problem they faced was the proliferation of NPLs. Many authorities temporarily nationalised banks. Their efforts also included bank closure and consolidation. In addition, Malaysia and Thailand established Danaharta and TAMC, respectively, as vehicles to restructure NPLs. ${ }^{10}$

In 1998, the Malaysian authorities established Danaharta as a public asset management company. The government funded Khazanah Nasional, the national investment arm for Malaysian government loans, granted loans to the agency. These loans were guaranteed through the issuance of Malaysian government zerocoupon bonds. Danaharta bought NPLs at market value, as appraised by independent auditors. ${ }^{11}$ Table 1 shows that the value of NPLs purchased by Danaharta from banks and financial companies was most significant in 1999 and 2000. The level of NPLs also declined from 1999 to 2000, and the NPL ratio has since declined every year after 1998, with the exception of 2001.

The consolidation of financial institutions is another measure which aims to improve the performance of the banking system. While there were some consolidations of commercial and merchant banks and finance companies, Bank Negara also provided liquidity to weakened financial institutions. ${ }^{12}$ In addition to this, some banks and their finance company subsidiaries were merged. As a result,

\footnotetext{
${ }^{10}$ The basic structures of Danaharta and TAMC are similar.

${ }^{11}$ This was for secured loans; Danaharta priced unsecured loans at $10 \%$ of the principal.

${ }^{12}$ The "merchant bank" in Malaysia changed to an "investment bank" in 2006.
} 
the number of commercial banks in Malaysia declined from 36 in 1997 to 22 at the beginning of $2007 .^{13}$ Bank ownership also changed. As the average level of foreign ownership increased, that of state ownership among the top 10 banks declined from $11 \%$ in 1997 to about $3.5 \%$ in 2004.

The Thai authorities established TAMC in 2001 with funding from the Financial Institutions Development Fund (FIDF), which guaranteed the issued bonds. ${ }^{14}$ As appraised by the FIDF, the pricing of private bank NPLs was derived from their collateral value. Table 1 demonstrates that the value of NPLs purchased did not fluctuate significantly. Even though its establishment took place after that of Danaharta in Malaysia, from 2001 to 2006, TAMC consistently bought between 680 and 780 billion baht of NPLs each year.. Unlike the experience of several other countries, in Thailand, some restructured loans returned to their nonperforming status because of the limitations on debt reduction during the restructuring process. Consolidation also took place among financial companies in Thailand (falling from 92 before the crisis to 18 in 2003), while bank mergers reduced the number of commercial banks. ${ }^{15}$ In total, eight commercial banks were merged with other banks between December 1997 and November 1999. The Thai authorities also attempted to support private bank recapitalisation directly, and had taken over six commercial banks by the summer of 1999. Although foreign ownership of banks in Thailand remains limited, average foreign ownership of the leading commercial banks has increased since 1999 because the Thai authorities have relaxed ownership limits.

\subsection{An overview of NPLs, real estate prices, and GDP growth}

This section graphically illustrates the fluctuations in NPLs, real estate prices, real GDP growth, and the value of purchased NPLs in Malaysia and Thailand. Figures 1 and 4 depict the ratio of NPLs to total loans and the real GDP growth rates, respectively. Figures 2 and 3 portray the housing price indexes in Malaysia and Thailand, respectively. Figure 5 shows the value of NPLs and loans purchased

\footnotetext{
${ }^{13}$ These include locally owned and foreign-owned banks.

${ }^{14}$ Before the establishment of TAMC, each bank set up its own asset management company. However, these private asset management companies could not significantly clear the amount of NPLs.

${ }^{15}$ The number of commercial banks declined in the aftermath of the crisis. However, they subsequently increased in number after this period, with 18 commercial banks operating by the beginning of 2007. 
by the asset management facility in Malaysia. Figure 6 depicts these same values for Thailand. Tables 2-1 and 2-2 provide further details on the loans purchased by the respective asset management companies and the NPL ratios of the Malaysian and Thai banks, respectively. ${ }^{16}$

As shown in Figure 1, Malaysia's NPL ratio increased to about 13.6\% in 1998. Since the crisis, Malaysian banks have improved their overall asset quality, and the NPL ratio has declined accordingly. Although the NPL ratio increased again in 2001, it decreased in the other years as a result of other forms of bank restructuring, e.g., through write-offs and asset sale programs. Figure 2 plots the fluctuation in the Malaysian house price index. As shown, house prices in Malaysia increased until 1997, going by about $18.3 \%$ in 1995 alone. The rate of change in house prices declined in 1998 and 1999 and increased thereafter. Figure 4 suggests that the Malaysian real GDP growth rate was negative in 1998 and lower in 2001 than in the other years. Together, these figures indicate that the decline in the NPL ratio and the increase in both house prices and the growth of real GDP were similar following the 1997 crisis. After the 1997 crisis, with the possible exception of 2001, economic growth and real estate prices increased, and NPLs declined in Malaysia. Conversely, in 2001, the GDP growth rate and real estate prices decreased, and the NPL ratio increased.

As shown in Figure 1, the NPL ratio in Thailand, which in 1998 had been about $43 \%$, decreased to about $7.3 \%$ in 2007 . Although the high NPL ratio of 1998 and 1999 had declined in 2000, recovery was slower in Thailand than in Malaysia. In 2006, the NPL ratio for private banks in Thailand remained higher than in Malaysia. The return to NPL status slowed after 2000, and the banking sector has generally become more profitable since 2003. However, we should note that the definition of NPLs changed in 2002, and this definition encompassed more NPLs as a result. Figure 3 demonstrates that house prices in Thailand increased until 1997, except in 1994. The rate of increase declined in 1998 and 1999 and increased again in 2002. As Figure 4 shows, the real GDP growth rate was negative in both 1997 and 1998. Since 1999, GDP growth in Thailand has remained positive. These observations indicate that the gradual decline in the NPL ratio, the increase in house prices, and the increase in the GDP growth rate were similar during the period after the 1997

\footnotetext{
${ }^{16}$ Tables 2-1 and 2-2 provide details only on the sample of banks included in the regression analysis.
} 
financial crisis. Since 2003, economic growth and real estate prices in Thailand have increased further, and NPLs have once again declined.

Figures 5 and 6 do not suggest a clear correlation between the changes in NPLs and loan transfers to the Malaysian and Thai asset management companies. Figure 5 indicates a reduction in NPLs and large loan transfers in 1999 in Malaysia. Figure 6 illustrates that in Thailand NPLs declined from 2002 to 2006 and that the values of loan transfers were similar from 2001 to 2006. However, it is clear that the loans purchased by asset management companies must have reduced the number of NPLs because the banks had sold them. Therefore, it is logical to conclude that the number of NPLs would have been larger in Malaysia and Thailand if their respective asset management companies had not purchased them.

Tables 2-1 and 2-2 also do not show a clear correlation between the loans purchased by the asset management companies and the NPLs for each bank in Malaysia and Thailand. In Thailand, the NPL ratios of banks that sold loans and those of banks that did not, both fell after 2000, even though TAMC did not exist and did not commence the purchase of loans until $2001 .{ }^{17}$ However, the NPL ratios of most banks in Malaysia were lower in 2000 than the period from 2001 to 2003 when Danaharta ceased buying loans.

\section{Empirical analysis}

\subsection{Methodology}

In this analysis, we examine the influence of bank characteristics, the purchases of nonperforming loans by asset management facilities, and macroeconomic indicators on the decline in NPLs in both Malaysia and Thailand. The analysis employs panel regression techniques, following previous studies that have focused on the relationship between the NPL ratio and other variables, such as the number of loans acquired, macroeconomic conditions, and bank performance. ${ }^{18}$ We focus on the influence of these same variables on the NPL ratio for domestic commercial and investment banks in Malaysia and domestic commercial banks in Thailand.

Following Ueda (2000), Hu et al. (2004), and Hosono (2010), the reduced-form regression equation for NPL ratios is as follows:

\footnotetext{
${ }^{17}$ The BankThai Public Company merged with the CIMB Thai Bank Public Company in 2009.

${ }^{18}$ As our analysis uses a reduced-form equation, we are unable to use the results to distinguish between demand and supply factors. 


$$
N P L_{i, t}=\alpha_{1}+\beta_{1} X_{i, t-1}+\beta_{2} \operatorname{Size}_{i, t-1}+\beta_{3} A M C_{i, t-1}+\beta_{4} M_{t-1}+\varepsilon_{i, t}
$$

where $N P L_{i t}$ is the ratio of NPLs to total loans (for bank $i$ in period $t$ ), $X_{i, t-1}$ is a bank characteristic variable representing bank performance, Size $e_{i, t-1}$ is a bank characteristic variable denoting bank size, $A M C_{i, t-1}$ is the value of loans sold to the public asset management company by each bank divided by total assets, $M_{t-1}$ is a macroeconomic variable denoting either the GDP growth rate or the real estate price index, and $\varepsilon_{i, t}$ is residual error. ${ }^{19}$

The bank characteristic variables include the logarithm of total bank assets $\left(\right.$ Size $\left._{i, t-1}\right)$ and bank risk. Bank performance $\left(X_{i, t-1}\right)$ is measured as equity divided by total assets $\left(\right.$ Equity $\left._{i, t-1}\right)$ or the return on assets $\left(R O A_{i, t-1}\right)$. The variables for macroeconomic conditions $\left(M_{t-1}\right)$ are real GDP growth rates $\left(\right.$ Growth $\left._{t-1}\right)$ or the rate of change in the real estate price index $\left(\operatorname{Land}_{t-1}\right) \cdot{ }^{20}$ We lag all explanatory variables one period. Table 3 provides the sample means and standard deviations of the variables.

If low-risk and large banks could eliminate NPLs and increase the number of new loans, the NPL ratio of these banks would be smaller than those of high-risk and small banks and the expected sign of the coefficients for the bank characteristic variables would be negative. ${ }^{21}$ Therefore, we expect the sign of the estimated

\footnotetext{
${ }^{19}$ We employed either a fixed or a random effects least squares regression technique according to the results of a Hausman test. The equation therefore includes either fixed or random effects.

${ }^{20}$ Because we omit inflation from the rate of change in the real estate price index, Land is in real values.

${ }^{21}$ Some theories assert that well-capitalized banks face lower insolvency risk and lower expected bankruptcy costs, and that a higher bank equity ratio implies lower risk. A high
} 
coefficients for Size and Equity or ROA to be negative when the disposal of NPLS depends on bank characteristics. In other words, if the banking sector reforms undertaken by the Malaysian and Thai authorities resulted in banks becoming sounder and larger after the Asian crisis and extensively eliminated NPLs, the signs of the estimated coefficients for the bank characteristic variables would be negative.

Because loans sold to the public asset management company can contribute to clearing off NPLs, the NPL ratios of banks can decline through the purchase of these loans by asset management companies. As a result, we expect the estimated coefficient for $A M C$ to be negative. ${ }^{22}$ Similarly, an increase in real estate prices can reduce NPLs through increases in collateral values, and high real GDP growth rates can transform some NPLs to normal loans by improving corporate performance. Therefore, favorable macroeconomic variables can reduce the number of NPLs. Accordingly, we anticipate that the estimated coefficients for Growth and Land will also be negative.

Along with these variables, we include dummy variables as constants and as slope coefficients. In order to better explore the influencing factors when banks did not sell loans, we specify these dummies for periods in which the asset management companies did not purchase NPLs. Although the transfer of bad loans can directly reduce NPLs, it is difficult to demonstrate exactly how the elimination of the NPLs could have taken place without the asset management companies purchasing the loans. Therefore, to consider the NPL situation as if there were no asset management companies in Malaysia or Thailand, we also investigate the effects of macroeconomic conditions and bank characteristics on the NPL ratio during the period when loan transfers did not occur. The regression equation used in this analysis is as follows:

$$
\begin{aligned}
& N P L_{i, t}=\alpha_{2}+\alpha_{3} \text { Dum }+\left(\beta_{5}+\gamma_{1} \text { Dum }\right) X_{i, t-1}+\left(\beta_{6}+\gamma_{2} \text { Dum }\right) \text { Size }_{i, t-1} \\
& +\beta_{7} A M C_{i, t-1}+\left(\beta_{8}+\gamma_{3} \text { Dum }\right) M_{t-1}+\varphi_{i, t}
\end{aligned}
$$

where Dum is a dummy variable taking a value of one in the period without the

\footnotetext{
level of ROA also implies a lower default risk.

${ }^{22}$ The possibility exists that bad banks sell more loans than good banks. Although this means that the coefficient can be positive, the regression results do not support this, as discussed later. 
purchase of NPLs by an asset management company and zero otherwise. Consequently, the dummy period in the regression for Malaysia is the period 2001-05 while that for Thailand is the period $1998-2001 .^{23}$ In the regression analysis of equation [2], the variables are otherwise the same as in equation [1].

Although the regression equations [1] and [2] use one-period lagged variables as a means of avoiding the problems of endogeneity, we can assume that the loans purchased by the asset management company and the macroeconomic variables also influence the results in any given year. Therefore, we also estimate the models using the dynamic panel regression method in Arellano and Bond (1991) in place of lagged variables. This is a generalized method of moments (GMM)-type estimation and specifies the equations in first differences with orthogonality conditions. ${ }^{24}$ The regression equations used in this analysis are as follows:

$$
\begin{aligned}
& N P L_{i t}=\delta_{1}+\theta_{1} N P L_{i, t-1}+\theta_{2} X_{i, t}+\theta_{3} \text { Size }_{i, t}+\theta_{4} A M C_{i, t}+\theta_{5} M_{t}+\phi_{i, t} \\
& N P L_{i, t}=\delta_{2}+\delta_{3} \text { Dum }+\theta_{6} N P L_{i, t-1}+\left(\theta_{7}+\mu_{1} \text { Dum }\right) X_{i, t}+\left(\theta_{8}+\mu_{2} \text { Dum }\right) \text { Size }_{i, t} \\
& +\theta_{9} A M C_{i, t}+\left(\theta_{10}+\mu_{3} \text { Dum }\right) M_{t}+v_{i, t}
\end{aligned}
$$

The specification of all variables is otherwise the same as in equations [1] and [2].

\subsection{Data and terms}

Given the constraints on data availability, we consider the periods 1998-2005 in Malaysia and 1998-2006 in Thailand. The periods during which loan transfers did not take place were 2001-05 in Malaysia and 1998-2000 in Thailand. The domestic bank panel data, including those for NPLs, equity, ROA, total loans, and total assets, are taken from the Bankscope database. The data for each bank that sold loans to a public asset management company are taken from Danaharta's operation reports in Malaysia and the annual reports of each individual bank in Thailand. The macroeconomic variables, including the GDP growth rate and the real estate price index, are from the databases of the CEIC Data Company Ltd. In the regression, we

\footnotetext{
${ }^{23}$ Although Danaharta purchased loans from some banks after 2002 in Malaysia, the purchased bank loans included in the regression analysis are only from the period 1998 to 2000.

${ }^{24}$ We employ first- and second-period lagged variables as instruments for the explanatory variables.
} 
specify the housing price indexes as the real estate price. ${ }^{25}$

The analysis specifies data for domestic commercial and investment banks in Malaysia and domestic commercial banks only in Thailand. ${ }^{26}$ Consequently, to obtain consistency in the statistical tests for Malaysia, we conduct separate regressions including both commercial and investment banks and commercial banks alone. ${ }^{27}$ We exclude banks from our samples that merged or ceased to operate after the crisis. ${ }^{28}$ Our final sample comprises 14 Malaysian domestic commercial and investment banks, including 9 commercial banks, and 10 Thai domestic commercial banks.

\subsection{Regression results}

Table 4 provides the results of the panel regressions of equation [1] for the NPL ratio of domestic banks in Malaysia and Thailand. ${ }^{29}$ For Malaysian commercial and investment banks, the coefficient for loans sold to Danaharta is not significant. ${ }^{30}$ The coefficients for Growth and Land are not negative. ${ }^{31}$ While the coefficients for Equity and $R O A$ are not significant, the coefficients for Size are significant and negative. In Malaysian commercial banks, the coefficients for Equity, ROA, and two of the coefficients for Size are significantly negative.

In Thailand, the estimated coefficients for loans purchased by TAMC are significant and negative. ${ }^{32}$ One of the coefficients for the real estate price index is

\footnotetext{
${ }^{25}$ Because the house price index for Thailand also includes housing land, the index is conceptually close to the real estate price index.

${ }^{26}$ The term "domestic bank" covers banks listed by local authorities.

${ }^{27}$ In Malaysia, most of the commercial banks are larger than the investment banks.

${ }^{28}$ We included the BankThai Public Company in Thailand as it merged in 2009. We excluded the Standard Chartered Bank in Thailand because we could not obtain data on its sale of loans to TAMC. A few commercial banks founded toward the middle of the 2000 s are also not included.

${ }^{29}$ Although there is a possibility of a correlation between some of the explanatory variables, the results of the regressions excluding one of the possibly correlated variables do not differ substantially from the original regression results.

${ }^{30}$ The data on NPLs and the balance sheet information for each bank do not suggest that the larger banks had smaller NPL ratios before authorities began attempting to eliminate the NPLs.

${ }^{31}$ The estimated coefficients for Land are significantly positive. We surmise that one reason for this finding is a situation in which NPL ratios and real estate prices declined in 1999 and increased in 2001.

${ }^{32}$ Because the definition of NPLs changed in 2002 and the number of NPLs increased, we also estimate an equation that includes a dummy variable for the year 2002 in the analyses 11
} 
significantly negative, while the coefficients for GDP growth rate are also significant and negative. The estimated coefficients for Equity and ROA are both insignificant. The coefficients for Size are significant and negative in all tests. This implies that faster economic growth, an increase in real estate prices, and an increase in loans sold to TAMC reduced the NPL ratio in Thailand. In addition, large banks may have had lower NPL ratios.

Table 5 depicts the results for the regressions of equation [2] for the dummy period in which banks did not sell loans to either Danaharta or TAMC. These results are similar to the regression results without the dummy variables. The estimated coefficients for Size are significant and negative in Malaysia. In addition, the coefficients for the Size dummies are significantly negative. This means that large banks had lower NPL ratios than small banks over the period 1998-2000. Remarkably, this persisted after 2001. The constant dummy variables are significantly positive in the tests for Malaysian banks. The positive constant dummy implies that NPL ratios increased in the period 2001-05 during which the asset management company did not purchase NPLs.

In Thailand, the coefficients for loans purchased by TAMC are significant and negative. While the estimated coefficients for Land are significantly negative and the corresponding coefficient dummies positive, the coefficient dummies for Growth are significantly negative. This implies that the real GDP ratio was more central to the decline in NPL ratios during the period 1998-2000, the period before TAMC began buying NPLs, than in the period after.

Table 6 details the results of the dynamic panel regressions of equation [3]. For Malaysian commercial and investment banks, one of the coefficients for loans sold to Danaharta and two of the coefficients for Size are significantly negative. However, the overidentifying restriction is not satisfied for this regression. In Malaysian commercial banks, two of the coefficients for loans sold to Danaharta are significant and negative. The estimated coefficients for Equity, ROA, Size, and Growth are also significantly negative. This implies that low-risk commercial banks had lower NPL ratios and that higher economic growth was important for the decline in NPLs for Malaysian commercial banks.

Coefficients for loans purchased by TAMC are significant and negative in Thailand. One of the coefficients for the GDP growth rate is significantly negative, 
as are the coefficients for the real estate price index. While the coefficient for ROA is significantly negative, the estimated coefficients for Size are statistically insignificant. This implies that high economic growth, an increase in real estate prices, and an increase in loans sold to TAMC reduced the NPL ratio of banks in Thailand.

Table 7 details the results of the dynamic regressions of equation [4] for the dummy period in which banks did not sell loans to the asset management companies. For Malaysian commercial and investment banks, some of the estimated slope coefficients for Size and the dummies of Size are significantly negative and the constant dummy variables are significantly positive. However, the overidentifying restriction is also unsatisfied for this regression. In Malaysian commercial banks, the coefficients for ROA, Equity, Size, and one of the coefficients for Growth are significant and negative. The constant dummy variables are significantly positive and two of the Size dummies are significantly negative.

In Thailand, the coefficients for loans purchased by TAMC and ROA are significant and negative. While the estimated coefficients for Land are not significant, one of the coefficient dummies for Growth is significantly negative. This suggests that real GDP was important for the fall in NPL ratios during 1998-2000.

\subsection{Influence of changes in bank loans on the NPL ratios}

We also test for the influence of bank characteristics, the purchase of loans by nonperforming asset management facilities, and macroeconomic conditions on changes in the loans for each bank. The regression on changes in bank loans can explain whether these influences on the ratios of NPLs to total loans arise from changes in loans (the denominator in the ratio). The rates of change in bank loans serve as dependent variables, and the explanatory variables are the same as in the tests for the NPL ratios in equation [1]. ${ }^{33}$ If the signs of the coefficients for AMC and the macroeconomic conditions variables are positive, their effects could increase bank loans and decrease the NPL ratio.

Table 8 shows the results of the panel regression of the rate of change in loans of domestic banks in Malaysia and Thailand. For Malaysian commercial and investment banks, the coefficients for Size are significant and negative. This implies

\footnotetext{
${ }^{33}$ The rate of change in bank loans is also in real values given that we exclude any inflationary effects.
} 
that large banks reduced both loans and NPLs during the regression period in Malaysia, because the regression for the NPL ratio showed that large banks had lower NPL ratios. Meanwhile, the coefficient for loans sold to Danaharta is significant and positive. This means that the purchase of loans by Danaharta may have increased banking loans and NPLs expanded during this same period because most of the estimated coefficients for $A M C$ were not significant in the regression result for the NPL ratios. In the test for Malaysian commercial banks, the estimated coefficients for Equity are significantly positive. This indicates that commercial banks with high equity ratios reduced their NPL ratios primarily through an increase in the number of loans (the denominator in the ratio).

For Thai banks, the coefficients for macroeconomic variables are significantly positive and the coefficients for loans purchased by TAMC are not significant. This implies that improvements in macroeconomic conditions reduced the NPL ratios primarily through an increase in the number of loans (the denominator) and that selling loans to TAMC reduced NPL ratios primarily through a reduction in the number of NPLs remaining on each bank's books (the numerator).

\subsection{Implications of regression results}

These findings support the argument that an improvement in macroeconomic circumstances and the purchase of NPLs may have affected the NPL problem in Thailand. In Malaysia, individual bank characteristics, notably bank size, exerted an enormous influence on the NPL problem. In addition, good performing Malaysian commercial banks also reduced their NPL ratios. ${ }^{34}$

It is possible that the increase in loans sold to Danaharta affected the NPL ratio, because some coefficients that were significant and the NPL ratio rose after the period in which the asset management company ceased purchasing loans. This is consistent with the high NPL ratios of most Malaysian banks from 2001 to 2003, as shown in Table 2-1. However, the role of the asset management company may have been smaller in solving the NPL problem in Malaysia than in Thailand. This implies that the number of NPLs could have declined sooner in Thailand if the authority had established TAMC prior to 2001.

\footnotetext{
${ }^{34}$ The difference in results for commercial and investment banks and commercial banks alone potentially suggests a difference in the contributing factors accounting for the decline in NPLs of commercial banks compared with investment banks in Malaysia.
} 


\section{Conclusion}

This study investigated the impact of variables that describe the characteristics of banks, the purchase of nonperforming loans by asset management facilities, and macroeconomic indicators on the decline of NPLs in Malaysia and Thailand. Both countries experienced the 1997 Asian Financial Crisis and faced similar problems with the amount of NPLs. In response, the Malaysian and Thai authorities established respective public asset management companies and attempted to reform their banking systems using various measures and policies to eliminate NPLs, including bank closure and consolidation. In addition, improved macroeconomic conditions in both countries after the crisis could also have affected the NPL problem. However, until now, the factors influencing the reduction in NPLs in the banking sectors of Southeast Asia have not been the subject of empirical attention. It is important to investigate these factors now in order to address similar problems if they were to reoccur in the future.

The panel regression results suggest that selling loans to public asset management companies was effective in reducing NPLs, especially in Thailand. This implies that Thai banks could have reduced their NPLs sooner if TAMC had existed before 2001. In Malaysia, although NPLs may have increased during the period in which Danaharta purchased loans, we cannot deny the existence of its influence in selling loans.

In addition, the results reveal that some variables measuring bank risk are significant in Malaysia. In Malaysia, domestic banks with larger assets have smaller NPL ratios. This suggests that large Malaysian banks could eliminate NPLs sooner than their smaller counterparts, and this trend was more significant in the period in which banks did not sell loans to Danaharta. In addition, commercial banks which perform well, generally have smaller NPL ratios in Malaysia. If banking reforms after the crisis contributed to creating sounder banks, this may have affected the decline in NPLs for banks and the overall improvement in the domestic banking sector in Malaysia.

While macroeconomic conditions caused the decrease in the NPL ratio principally by increasing loans in Thailand, the effect was more significant than in Malaysia. ${ }^{35}$ In addition, if the Thai authorities had not established TAMC, solving

\footnotetext{
${ }^{35}$ If real estate prices play an important role in the decline in NPLs, this is also consistent with the influential role of collateralised real estate on bank loans in Thailand. 
the NPL problem would have largely depended on the general improvement in macroeconomic conditions. This implies that macroeconomic recovery from the financial crisis of 1997 affected largely the reduction in NPL ratios and that macroeconomic policy may have had played an important role in resolving the NPL problem in Thailand. 


\section{References}

Arellano, M \& Bond, S 1991, 'Some Tests of Specification for Panel Data: Monte Carlo Evidence and an Application to Employment Equations', Review of Economic Studies, 58 (2), pp. 277-97.

Berger, A \& DeYoung, R 1997, 'Problem Loans and Cost Efficiency in Commercial Banks', Journal of Banking and Finance, 21, pp. 849-870.

Bonin, JP \& Huang, Y 2001, 'Dealing with the Bad Loans of the Chinese Banks', Journal of Asian Economics, 12, pp. 197-214.

Boudriga, A, Boulila, N \& Jellouli, S, 2009, 'Does Bank Supervision Impact Nonperforming Loans: Cross-Country Determinants Using Aggregate Data?', MPRA Paper, No. 18068.

Fung, B, George, J Hohl, S \&Ma, G, 2004, 'Public Asset Management Companies in East Asia: A Comparative Study' BIS Occasional Paper, No. 3.

Hilbers, P, Lei, Q \& Zacho, L 2001 'Real Estate Market Developments and Financial Sector Soundness', IMF Working Paper, WP/01/129.

Hasan, I \& Wall, LD 2004, 'Determinants of the Loan Loss Allowance: Some CrossCountry Comparisons', The Financial Review, 39, pp. 129-152.

Hosono, K 2010, Kinyukiki no Mikurokeizai Bunseki [Microeconomic Analysis of Financial Crises]. University of Tokyo Press, Tokyo (in Japanese).

$\mathrm{Hu}, \mathrm{JL}, \mathrm{Li}$, YA \& Chiu, YH 2004, 'Ownership and Nonperforming Loans: Evidence from Taiwan's banks', The Developing Economies, 42 (3), pp. 405-420.

International Monetary Fund, 2004, 'Thailand: Selected Issues', IMF Country Report No. 04/1.

Ito, T 1999,' Asia Tsukakiki no Haikei' [The Background of the Asian Crisis]. Kaihatsuenjyo Kenkyu [Research on Development Aid] 5(4), pp.102-29. (in Japanese).

Ogawa, K \& Kitasaka, S 2000, 'Bank Lending in Japan: Its Determinants and Macroeconomic Implications', In Crisis and Change in the Japanese Financial System, T Hoshi \& HT Patrick (eds.), Kluwer Academic Publishers, Massachusetts, pp. 159-200.

Sinkey, JF Jr \& Greenawalt, M 1991,'Loan-Loss Experience and Risk-Taking Behavior at Large Commercial Banks', Journal of Financial Services Research, 5, pp. 43- 
59.

Terada-Hagiwara, A \& Pasadilla, G 2004, 'Experience of Asian Asset Management Companies: Do They Increase Moral Hazard? Evidence from Thailand', $A D B$ ERD Working Paper, No. 55.

Ueda, K 2000, 'Causes of Japan's Banking Problems in the 1990s', In Crisis and Change in the Japanese Financial System, T Hoshi \& HT Patrick (eds.), Kluwer Academic Publishers, Massachusetts, pp. 59-81. 
Figure 1: Ratio of NPLs to total loans

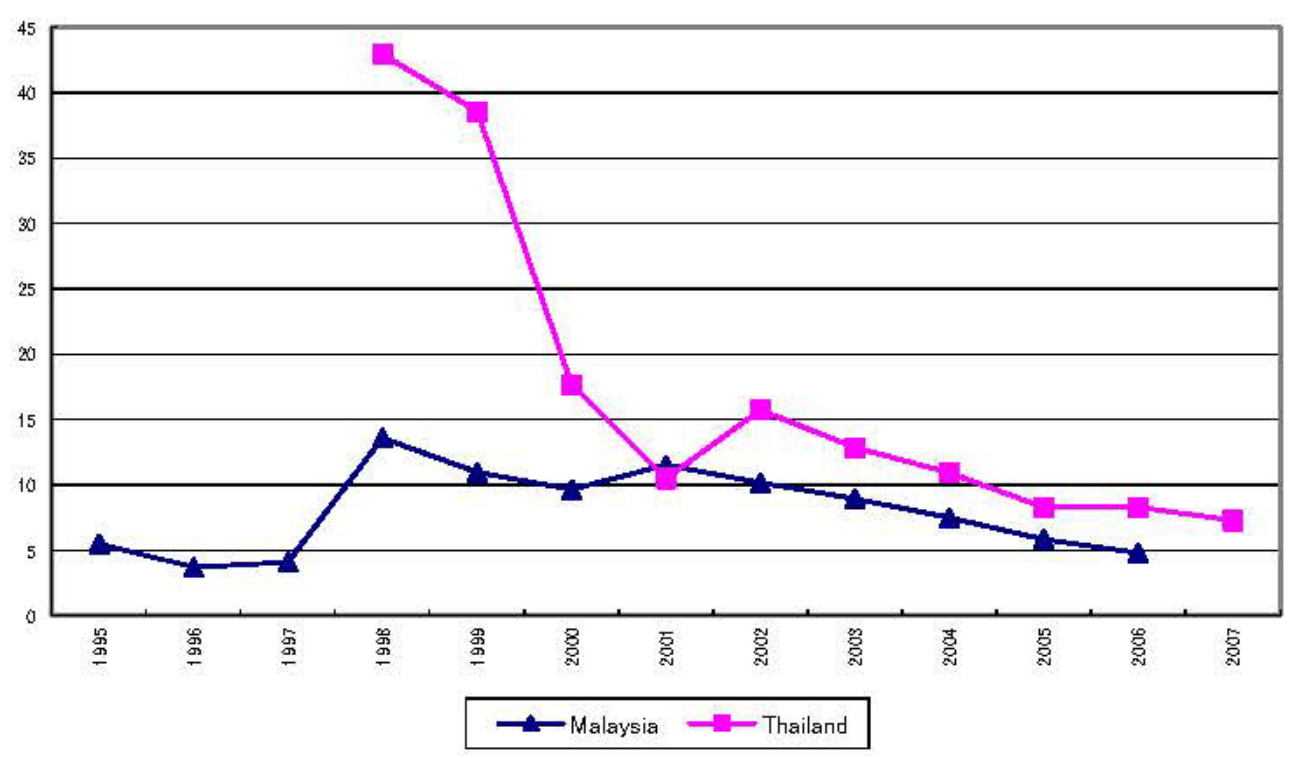

Figure 2: Real estate price index in Malaysia (Housing price index)

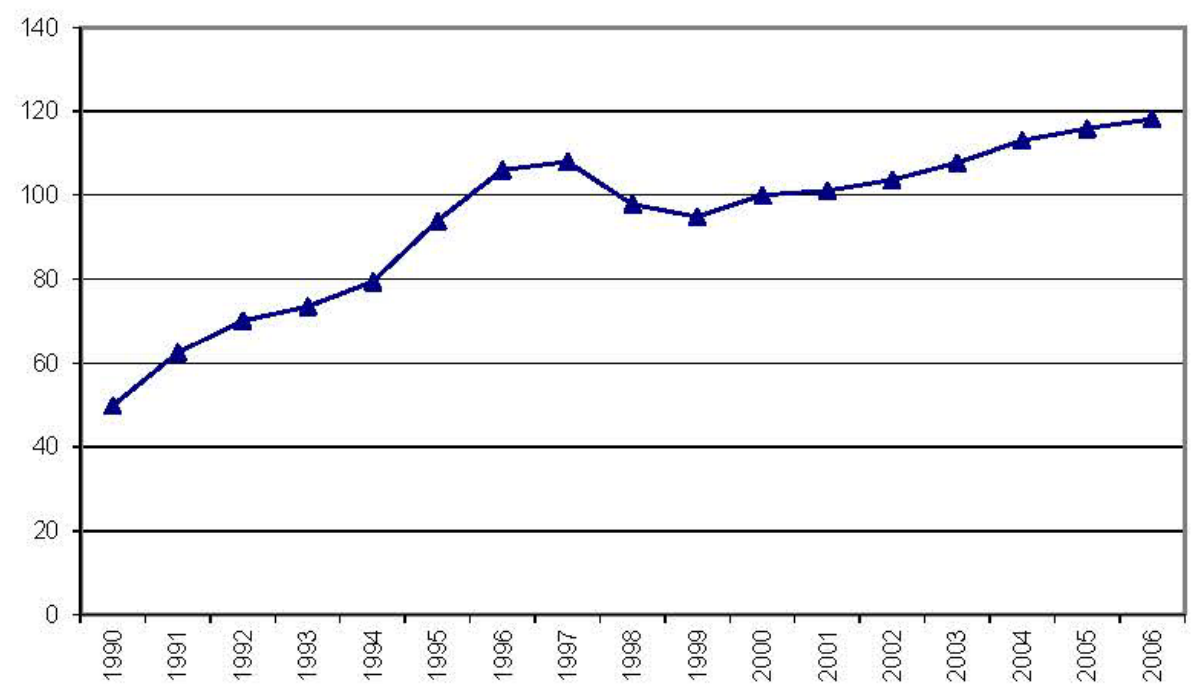


Figure 3: Real estate price index in Thailand (Housing price index)

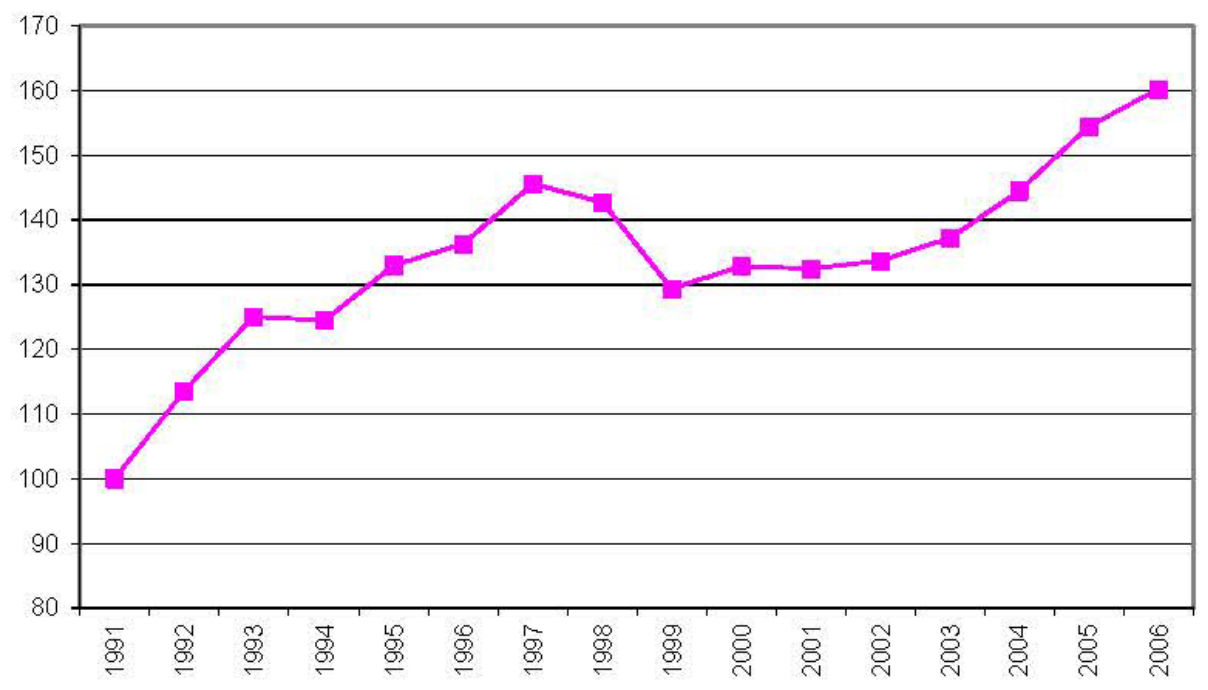

Figure 4: Real GDP growth rate

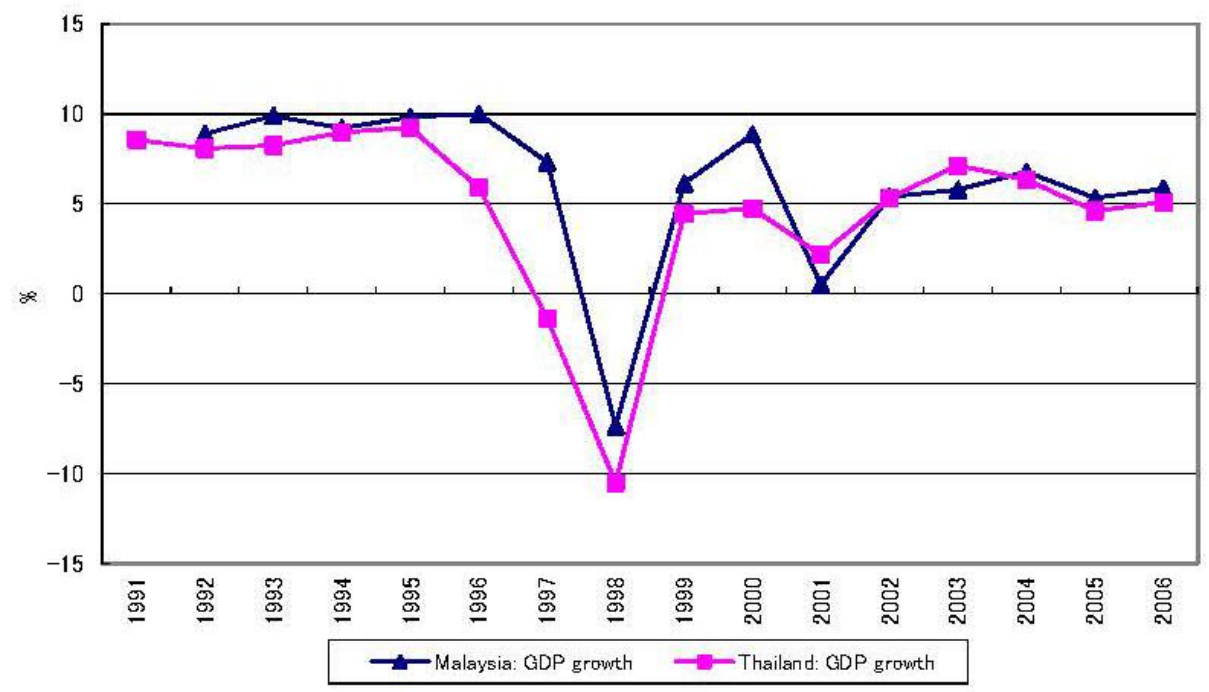


Figure 5: NPLs and loan transfers in Malaysia

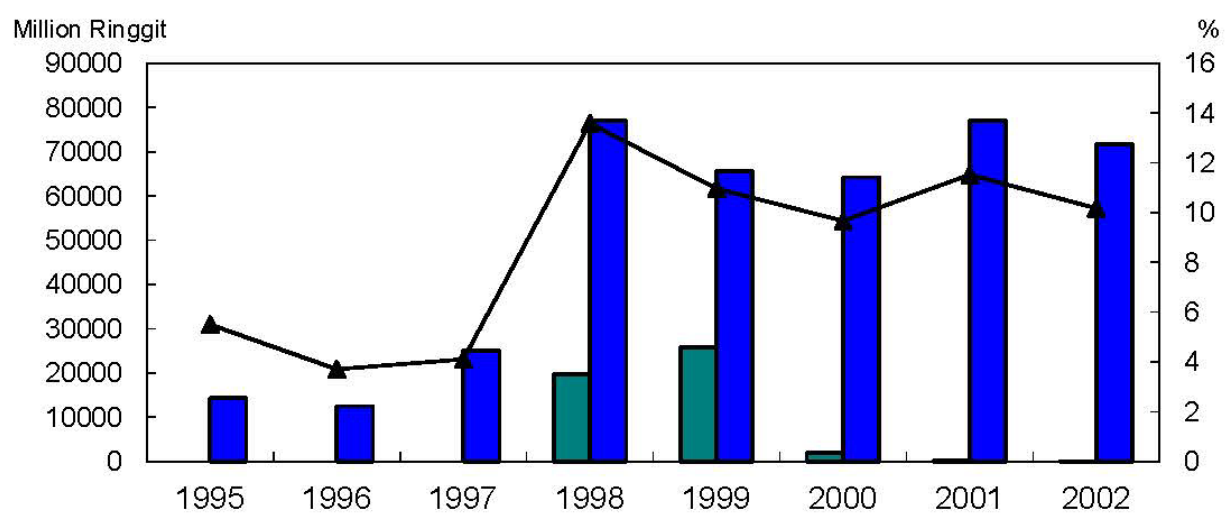

Figure 6: NPLs and loan transfers in Thailand

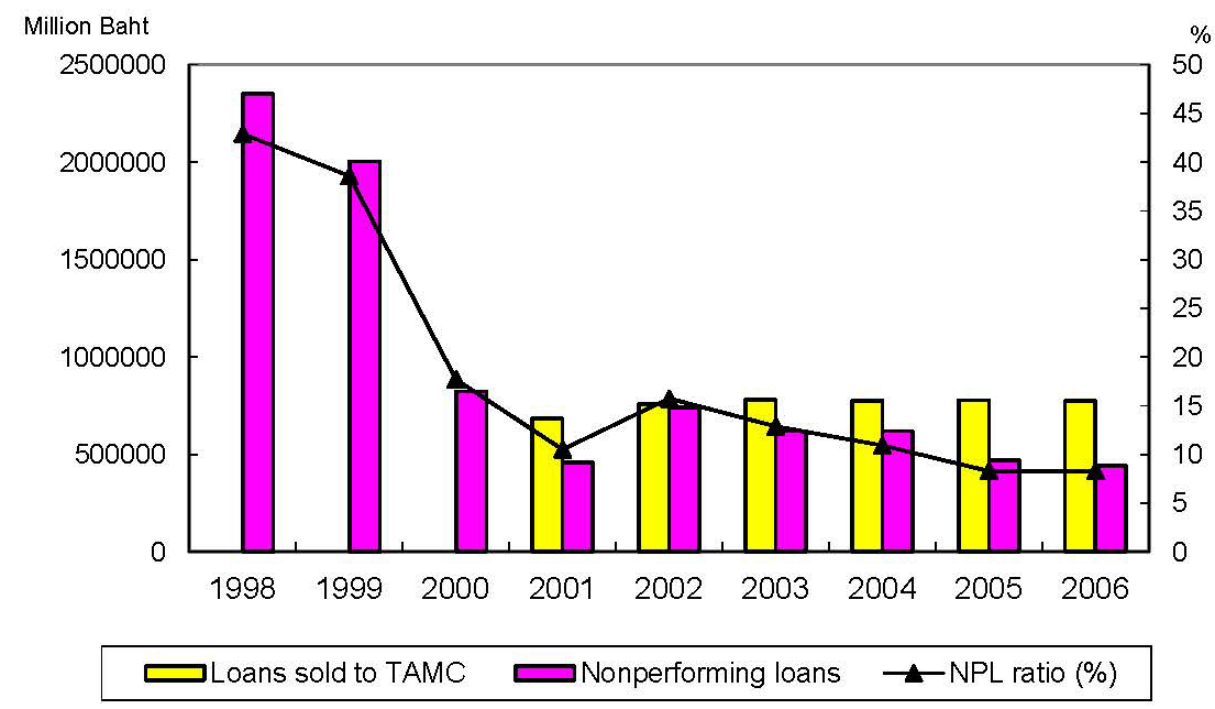


Table 1: Value of loan transfers

\begin{tabular}{lcc}
\hline & Malaysia & Thailand \\
\hline 1998 & $\begin{array}{c}\text { Loans acquired by Danaharta } \\
\text { (Million Ringgit) }\end{array}$ & $\begin{array}{c}\text { Loans sold to TAMC } \\
\text { (Million Baht) }\end{array}$ \\
\cline { 2 - 3 } 1999 & 19727.7 & \\
2000 & 25793 & \\
2001 & 1967.2 & 684572 \\
2002 & 231 & 759360 \\
2003 & 43 & 780824 \\
2004 & & 776959 \\
2005 & & 777179 \\
2006 & & 775778 \\
\hline
\end{tabular}


Table 2-1: Nonperforming loan ratios and loans sold to Danaharta: Malaysian banks

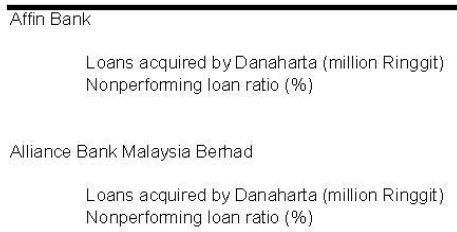

EON Bank Berhad

Loans acquired by Danaharta (million Ringgit) Nonperforming loan ratio (\%)

Hong Leong Bank Berhad

Loans acquired by Danaharta (million Ringgit) Nonperforming loan ratio (\%)

Malayan Banking Berhad - Maybank

Loans acquired by Danaharta (million Ringgit) Nonperforming loan ratio (\%)

Public Bank Berhad

Loans acquired by Danaharta (million Ringgit) Nonperforming loan ratio (\%)

RHB Bank Berhad

Loans acquired by Danaharta (million Ringgit) Nonperforming loan ratio (\%)

Southern Bank Berhad

Loans acquired by Danaharta (million Ringgit) Nonperforming loan ratio (\%)

CIMB Bank Berhad

Loans acquired by Danaharta (million Ringgit) Nonperforming loan ratio (\%)

Amlnvestment Bank Berhad

Loans acquired by Danaharta (million Ringgit) Nonperforming loan ratio (\%)

MIDF Amanah Investment Bank Berhad

Loans acquired by Danaharta (million Ringgit) Nonperforming loan ratio (\%)

RHB Investment Bank Bhd

Loans acquired by Danaharta (million Ringgit) Nonperforming loan ratio (\%)

CIMB Investment Bank Berhad

Loans acquired by Danaharta (million Ringgit) Nonperforming loan ratio (\%)

Affin Investment Bank Berhad

Loans acquired by Danaharta (million Ringgit) Nonperforming loan ratio (\%)

\begin{tabular}{rrrrrrrr}
1998 & 1999 & 2000 & 2001 & 2002 & 2003 & 2004 & 2005 \\
\hline 4.2 & 194.8 & 30.5 & 0 & 0 & 0 & 0 & 0 \\
18.06 & 17.10 & 14.37 & 35.48 & 37.74 & 35.83 & 26.69 & 17.40
\end{tabular}

\begin{tabular}{rrrrrrrr}
1998 & 1999 & 2000 & 2001 & 2002 & 2003 & 2004 & 2005 \\
\hline 27.1 & 259 & 12.5 & 0 & 0 & 0 & 0 & 0 \\
16.32 & 15.77 & 16.76 & 18.70 & 20.61 & 18.03 & 15.51 & 13.37
\end{tabular}

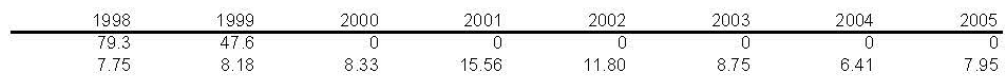

\begin{tabular}{rrrrrrrr}
1998 & 1999 & 2000 & 2001 & 2002 & 2003 & 2004 & 2005 \\
\hline 0 & 133.5 & 14.3 & 0 & 0 & 0 & 0 & 0 \\
10.57 & 13.43 & 10.98 & 12.61 & 12.81 & 11.90 & 8.88 & 6.26
\end{tabular}
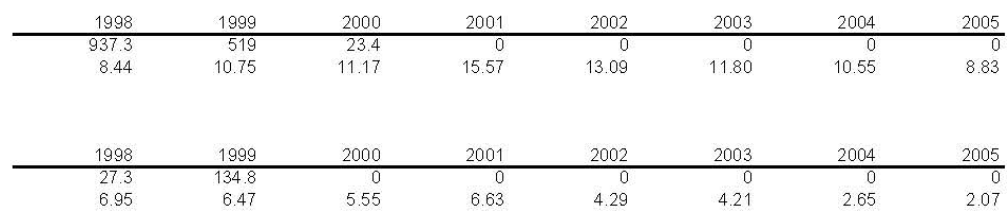

\begin{tabular}{rrrrrrrr}
1998 & 1999 & 2000 & 2001 & 2002 & 2003 & 2004 & 2005 \\
\hline 0 & 2185.1 & 13.2 & 0 & 0 & 0 & 0 & 0 \\
10.05 & 7.82 & 8.28 & 11.66 & 16.11 & 16.20 & 13.17 & 8.25
\end{tabular}
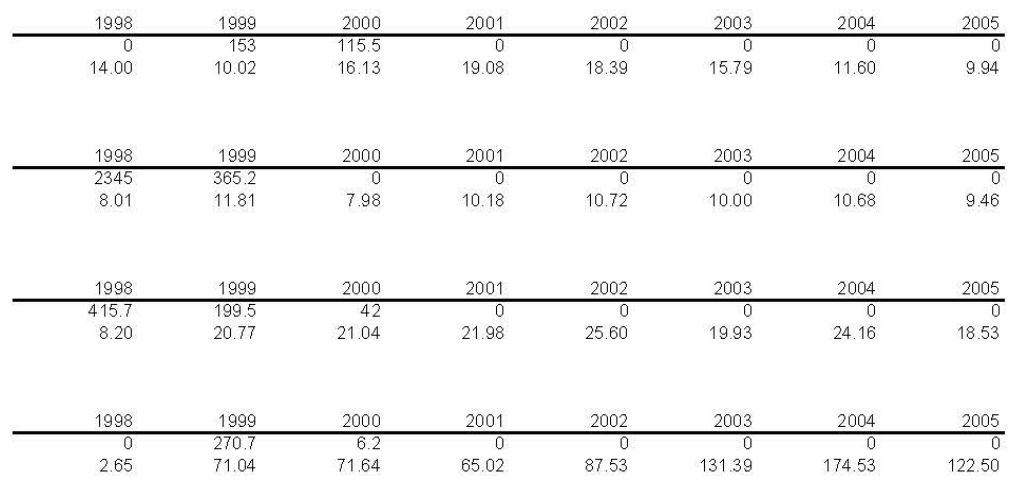

\begin{tabular}{rrrrrrrr}
1998 & 1999 & 2000 & 2001 & 2002 & 2003 & 2004 & 2005 \\
\hline 54.8 & 244.6 & 0 & 0 & 0 & 0 & 0 & 0 \\
9.19 & 11.70 & 14.07 & 30.86 & 49.22 & 45.27 & 31.30 & 25.86
\end{tabular}

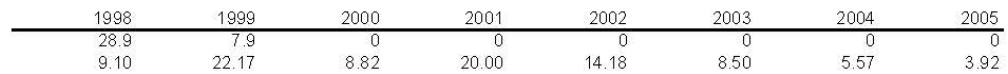

\begin{tabular}{rrrrrrrr}
1998 & 1999 & 2000 & 2001 & 2002 & 2003 & 2004 & 2005 \\
\hline 75.3 & 30.2 & 755.1 & 0 & 0 & 0 & 0 & 0 \\
16.56 & 46.61 & 40.05 & 62.84 & 79.55 & 93.15 & 74.27 & 41.33
\end{tabular}

Notes: This table details only banks that are covered in the regression analysis. 


\section{Table 2-2: Nonperforming loan ratios and loans sold to TAMC: Thai banks}

Bangkok Bank Public Company Limited

Loans sold to TAMC (million Baht) Nonperforming loan ratio (\%)

Krung Thai Bank Public Company Limited

Loans sold to TAMC (million Baht) Nonperforming loan ratio $(\%)$

Siam Commercial Bank Public Company Limited

Loans sold to TAMC (million Baht) Nonperforming loan ratio $(\%)$

Kasikornbank Public Company Limited

Loans sold to TAMC (million Baht) Nonperforming loan ratio $(\%)$

TMB Bank Public Company Limited

Loans sold to TAMC (million Baht) Nonperforming loan ratio $(\%)$

Bank of Ayudhya Public Company Ltd.

Loans sold to TAMC (million Baht) Nonperforming loan ratio (\%)

Bankthai Public Company Limited

Loans sold to TAMC (million Baht) Nonperforming loan ratio $(\%)$

United Overseas Bank (Thai) PCL

Loans sold to TAMC (million Baht) Nonperforming loan ratio $(\%)$

Tisco Bank Public Company Limited

Loans sold to TAMC (million Baht) Nonperforming loan ratio $(\%)$

Kiatnakin Bank Public Company Limited

Loans sold to TAMC (million Baht) Nonperforming loan ratio $(\%)$

\begin{tabular}{rrrrrrrrr}
1998 & 1999 & 2000 & 2001 & 2002 & 2003 & 2004 & 2005 & 2006 \\
\hline 0 & 0 & 0 & 22457.1 & 24829.7 & 25396.2 & 25423.9 & 25550.1 & 25515.7 \\
49.20 & 48.55 & 23.63 & 21.91 & 26.00 & 24.83 & 17.01 & 11.03 & 9.30
\end{tabular}
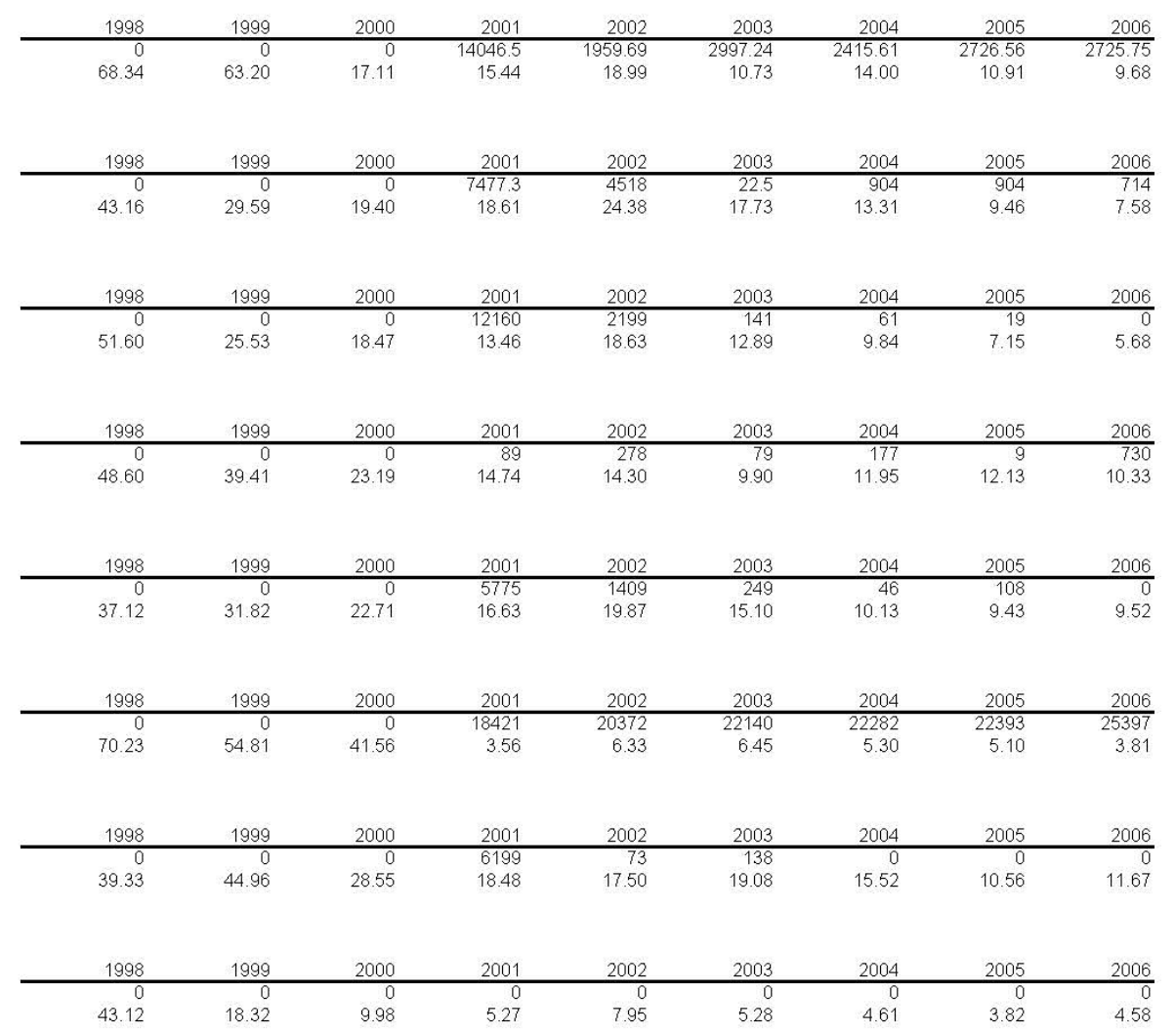

\begin{tabular}{rrrrrrrrr}
1998 & 1999 & 2000 & 2001 & 2002 & 2003 & 2004 & 2005 & 2006 \\
\hline 0 & 0 & 0 & 0 & 0 & 0 & 0 & 0 \\
54.49 & 35.31 & 22.80 & 10.94 & 8.56 & 11.82 & 11.20 & 17.69 & 14.78 \\
\hline
\end{tabular}

Notes: This table details only banks that are covered in the regression analysis. 
Asia Pacific Economic Papers

Table 3: Basic statistics

\begin{tabular}{lrrrr}
\hline & Malaysia & \multicolumn{3}{c}{ Thailand } \\
\hline & Mean & Std. Dev. & Mean & Std. Dev. \\
\hline NPL ratio & & & & \\
ROA & 0.229008 & 0.274057 & 0.206281 & 0.157137 \\
Equity & 0.488259 & 2.112336 & -0.667111 & 4.434409 \\
Size & 0.101075 & 0.038378 & 0.086027 & 0.057692 \\
Land & 23.578100 & 1.390398 & 26.524760 & 1.175597 \\
Growth & -0.013010 & 0.058260 & -0.013472 & 0.038928 \\
AMC & 0.047521 & 0.058194 & 0.030466 & 0.039780 \\
& 0.009145 & 0.042008 & 0.008462 & 0.022655 \\
\hline
\end{tabular}


Table 4: Determinants of nonperforming loan ratios

\begin{tabular}{|c|c|c|c|c|c|c|c|c|c|c|c|c|}
\hline & \multicolumn{4}{|c|}{ Malaysia (Commercial and investment banks) } & \multicolumn{4}{|c|}{ Malaysia (Commercial banks) } & \multicolumn{4}{|l|}{ Thailand } \\
\hline $\begin{array}{c}R O A \text { it } 1 \\
\text { sttent }\end{array}$ & $\begin{array}{r}-0.98660 \\
1.20334\end{array}$ & & $\begin{array}{r}-0.96594 \\
1.28811\end{array}$ & & $\begin{array}{c}-4.06231 \cdots \\
0.64005\end{array}$ & & $\begin{array}{c}-3.82956 \cdots \\
0.76118\end{array}$ & & $\begin{array}{r}-0.00230 \\
0.00517\end{array}$ & & $\begin{array}{r}0.00420 \\
0.02274\end{array}$ & \\
\hline $\begin{array}{c}\text { Equity it.l } \\
\text { sthen. }\end{array}$ & & $\begin{array}{r}-0.78972 \\
0.664019\end{array}$ & & $\begin{array}{r}-0.67512 \\
0.68873\end{array}$ & & $\begin{array}{c}-1.23834 \quad \cdots \\
0.3310\end{array}$ & & $\begin{array}{c}-1.14855 \\
0.35543\end{array}$ & & $\begin{array}{r}-0.46961 \\
0.521201\end{array}$ & & $\begin{array}{r}0.20925 \\
033685\end{array}$ \\
\hline $\begin{array}{l}\text { Size it.1 } \\
\text { sther. }\end{array}$ & $\begin{array}{c}-0.13448 \cdots \\
0.04635\end{array}$ & $\begin{array}{c}-0.16138 \cdots \\
0.02893\end{array}$ & $\begin{array}{c}-0.08812 \\
0.04524\end{array}$ & $\begin{array}{c}-0.14928 \cdots \\
0.02496\end{array}$ & $\begin{array}{c}-0.02929 \cdots \\
0.0101010\end{array}$ & $\begin{array}{c}-0.04027 \cdots \\
0.01406\end{array}$ & $\begin{array}{r}-0.01579 \\
0.01032\end{array}$ & $\begin{array}{r}-0.02090 \\
0.01333\end{array}$ & $\begin{array}{c}-0.24068 \cdots \\
0.06809\end{array}$ & $\begin{array}{c}-0.21294 \cdots \\
0.07632\end{array}$ & $\begin{array}{c}-0.13091 \\
0.04380\end{array}$ & $\begin{array}{c}-0.12394 " \\
0.04930\end{array}$ \\
\hline $\begin{array}{l}\text { Land } n=1 \\
\quad \text { stler. }\end{array}$ & $\begin{array}{c}0.76198 \cdots \\
0.28030\end{array}$ & $\begin{array}{c}0.81219 \cdots \\
027037\end{array}$ & & & $\begin{array}{c}0.41347 \cdots \\
0.08759\end{array}$ & $\begin{array}{c}0.26559 \cdots \\
0.09390\end{array}$ & & & $\begin{array}{r}-0.68424 \\
0.49942\end{array}$ & $\begin{array}{c}-0.75573 \\
0.38175\end{array}$ & & \\
\hline $\begin{array}{l}\text { Growth } x-1 \\
\text { stlen. }\end{array}$ & & & $\begin{array}{r}0.08134 \\
0.2706\end{array}$ & $\begin{array}{r}0.14291 \\
0.27498\end{array}$ & & & $\begin{array}{c}0.15937 \\
0.09285\end{array}$ & $\begin{array}{r}-0.02067 \\
0.08474\end{array}$ & & & $\begin{array}{c}-2.56106 \cdots \\
0.23186\end{array}$ & $\begin{array}{c}-2.46404 \cdots \\
022481\end{array}$ \\
\hline $\begin{array}{r}A M C \text { int } \\
\text { stien. }\end{array}$ & $\begin{array}{r}-0.41643 \\
0.44463\end{array}$ & $\begin{array}{r}-0.19603 \\
038722\end{array}$ & $\begin{array}{r}-0.45935 \\
0.40778\end{array}$ & $\begin{array}{r}-0.25969 \\
0.49423\end{array}$ & $\begin{array}{r}0.29081 \\
0.31898\end{array}$ & $\begin{array}{r}0.37137 \\
0.34847\end{array}$ & $\begin{array}{r}-0.08798 \\
0.35585\end{array}$ & $\begin{array}{r}0.07725 \\
0.3066\end{array}$ & $\begin{array}{c}-2.07634 \\
1.06166\end{array}$ & $\begin{array}{c}-2.52491 " \\
1.10841\end{array}$ & $\begin{array}{c}-1.51116 " \\
0.66751\end{array}$ & $\begin{array}{r}-1.16157 \\
0.71571\end{array}$ \\
\hline $\begin{array}{l}\text { Constant } \\
\text { sttenx. }\end{array}$ & $\begin{array}{c}3.40920 \cdots \\
1.09012\end{array}$ & $\begin{array}{c}4.11435 \cdots \\
0.62322\end{array}$ & $\begin{array}{c}2.30576 " \\
1.06009\end{array}$ & $\begin{array}{c}3.80110 \cdots \\
0.62866\end{array}$ & $\begin{array}{c}0.87316 \cdots \\
0.2458\end{array}$ & $\begin{array}{c}1.21312 \cdots \\
0.3509\end{array}$ & $\begin{array}{c}0.53181 \text { " } \\
0.29974\end{array}$ & $\begin{array}{c}0.73403 " ~ \\
0.34444\end{array}$ & $\begin{array}{c}6.57889 \\
1.80214\end{array}$ & $\begin{array}{c}5.88711 \cdots \\
1.9312\end{array}$ & $\begin{array}{c}3.73132=\cdots \\
1.15833\end{array}$ & $\begin{array}{c}3.52194 \quad \cdots \\
128742\end{array}$ \\
\hline R.sq & 0.120 & 0.525 & 0.052 & 0.494 & 0.541 & 0.384 & 0.461 & 0.331 & 0.397 & 0.402 & 0.763 & 0.736 \\
\hline smple size & 112 & 112 & 112 & 112 & 72 & 72 & 72 & 72 & 90 & 90 & 90 & 90 \\
\hline
\end{tabular}

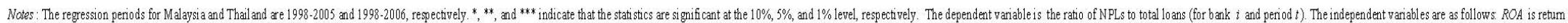
on assets, Equaty is equity divided by total assets, Size is equity divided by total assets, Land is the rate of change in the real estate price indez, Growth is real GDP growth rates, AMC is he value of loans sold to the public asset managgement compann by each bank divided by total assets. 
Table 5: Determinants of nonperforming loan ratios: the regression with dummies

\begin{tabular}{|c|c|c|c|c|c|c|c|c|c|c|c|c|}
\hline \multirow{3}{*}{ 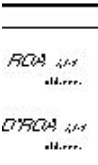 } & \multicolumn{4}{|c|}{ Malaysia (Commercial and investment banks) } & \multicolumn{4}{|c|}{ Malaysia (Commercial banks) } & \multicolumn{4}{|l|}{ Thailand } \\
\hline & $\begin{array}{c}-4.42789 \cdots \\
1.5934\end{array}$ & & $\begin{array}{c}-4.50924 \ldots \\
1.20 w\end{array}$ & & $\begin{array}{r}-0.13539 \\
1.19193\end{array}$ & & $\begin{array}{r}-0.13477 \\
1.913 !\end{array}$ & & $\begin{array}{r}-0.00427 \\
1.1 .12 a\end{array}$ & & $\begin{array}{r}-0.00204 \\
. .1145\end{array}$ & \\
\hline & $\begin{array}{r}1.83054 \\
1.31 \mathrm{mss}\end{array}$ & & 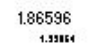 & & $\begin{array}{r}-3.74769 \\
1.9155\end{array}$ & & $\begin{array}{r}-3.69265 \\
1.313 \cdots\end{array}$ & & $\begin{array}{r}-0.00375 \\
. .115\end{array}$ & & $\begin{array}{r}0.00750 \\
. .1612\end{array}$ & \\
\hline 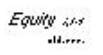 & & $\begin{array}{r}-0.74026 \\
\text {..64" }\end{array}$ & & $\begin{array}{r}-0.75086 \\
\mathbf{1 . 6 4 7 + 1}\end{array}$ & & $\begin{array}{r}-0.80488 \\
-1.2 z 64\end{array}$ & & $\begin{array}{r}-0.79139 \\
\text { L.t2an }\end{array}$ & & $\begin{array}{r}-0.13226 \\
. .2741\end{array}$ & & $\begin{array}{r}-0.22133 \\
.1 .91211\end{array}$ \\
\hline 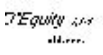 & & $\begin{array}{r}-0.27674 \\
. . m,\end{array}$ & & $\begin{array}{r}-0.27124 \\
. .1321\end{array}$ & & $\begin{array}{r}-0.58551 \\
. .4631\end{array}$ & & $\begin{array}{r}-0.57713 \\
\text { L.stur }\end{array}$ & & $\begin{array}{r}-0.72914 \\
\mathbf{1 . 5 4 2 3 1}\end{array}$ & & $\begin{array}{r}-0.79424 \\
\mathbf{1 . 5 8 1 4}\end{array}$ \\
\hline Sise in. & $\begin{array}{c}-0.060655 . . \\
\text {..125s }\end{array}$ & $\begin{array}{l}-0.10015 \cdots \\
\quad . .12 m\end{array}$ & $-0.06058 \cdots$ & $\begin{array}{c}-0.09987 \cdots \\
0.02776\end{array}$ & 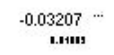 & 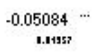 & $\begin{array}{c}-0.03203 \cdots \\
0.01082\end{array}$ & $\begin{array}{c}-0.04958 \cdots \\
0.01346\end{array}$ & $\begin{array}{r}0.00987 \\
0.01254\end{array}$ & $\begin{array}{r}0.00724 \\
0.01632\end{array}$ & $\begin{array}{c}-0.12390 \cdots \\
0.04781\end{array}$ & $\begin{array}{c}0.00438 \\
0.01759\end{array}$ \\
\hline anse ins & $\begin{array}{l}-0.11318 \cdots \\
.1 .12582\end{array}$ & $\begin{array}{c}-0.10734 \\
-1.2331\end{array}$ & $\begin{array}{l}1.86596 \ldots \\
1.99864\end{array}$ & $\begin{array}{c}-0.10698 \\
0.02405\end{array}$ & $\begin{array}{r}-0.02205 \\
1.11+1\end{array}$ & $\begin{array}{r}-0.02225 \\
.1 .12228\end{array}$ & -0.02214 & $\begin{array}{r}-0.02156 \\
0.01250\end{array}$ & $\begin{array}{r}0.00045 \\
0.01251\end{array}$ & $\begin{array}{r}-0.00628 \\
0.01629\end{array}$ & $\begin{array}{r}0.00895 \\
0.01555\end{array}$ & $\begin{array}{r}-0.00257 \\
0.01916\end{array}$ \\
\hline Land fl... & $\begin{array}{c}-0.36888 \\
0.43248\end{array}$ & $\begin{array}{c}-0.60923 \\
. .9435\end{array}$ & & & $\begin{array}{r}0.01715 \\
0.15929\end{array}$ & $\begin{array}{r}0.00281 \\
1.12161\end{array}$ & & & $\begin{array}{c}-1.77665 \\
\text {...3" }\end{array}$ & $\begin{array}{r}-1.86369 \\
1.7667\end{array}$ & & \\
\hline 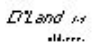 & $\begin{array}{r}-1.17047 \\
1.29471\end{array}$ & $\begin{array}{r}-0.88547 \\
1.665\end{array}$ & & & $\begin{array}{r}-0.02562 \\
0.368663\end{array}$ & $\begin{array}{r}-0.48008 \\
. .153, \prime\end{array}$ & & & $\begin{array}{l}5.19888 \cdots \\
. .11+12\end{array}$ & $\begin{array}{c}4.72726 \cdots \\
. .1 .26\end{array}$ & & \\
\hline Mrowests. & & & $\begin{array}{c}-0.40374 \\
\text {....1.14 }\end{array}$ & $\begin{array}{r}-0.67358 \\
. .3194\end{array}$ & & & $\begin{array}{r}0.20183 \\
\text { 1.915n }\end{array}$ & $\begin{array}{r}0.00372 \\
\text { L.193! }\end{array}$ & & & $\begin{array}{c}-0.61977 \\
., m a s\end{array}$ & $\begin{array}{r}-0.51296 \\
. .1112\end{array}$ \\
\hline Thats as & & & $\begin{array}{r}0.08715 \\
\text { s.1.14:4 }\end{array}$ & $\begin{array}{r}0.37497 \\
\text { L.13!" }\end{array}$ & & & $\begin{array}{r}-0.04533 \\
\mathbf{L}+13 m\end{array}$ & $\begin{array}{r}-0.17062 \\
\text { L.142:4 }\end{array}$ & & & $\begin{array}{l}-2.450600 . \\
. .4551\end{array}$ & $\begin{array}{r}-2.81743 \\
1.1 \mathrm{ma}\end{array}$ \\
\hline 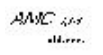 & $\begin{array}{r}-0.18958 \\
-1.4+11\end{array}$ & $\begin{array}{r}0.02077 \\
1.9145\end{array}$ & $\begin{array}{r}-0.22625 \\
\text { 1.4.4. }\end{array}$ & $\begin{array}{r}-0.01173 \\
. .1+117\end{array}$ & $\begin{array}{l}0.20194 \\
.19621\end{array}$ & $\begin{array}{r}0.31489 \\
1.92521\end{array}$ & $\begin{array}{r}0.20183 \\
\text { 1.1.15s? }\end{array}$ & $\begin{array}{r}0.31545 \\
\text { L.:22u1 }\end{array}$ & $\begin{array}{c}-1.15799 \\
\text {-.411" }\end{array}$ & $\begin{array}{c}-1.39634 \\
. .532 y\end{array}$ & $\begin{array}{c}-1.60225 \\
. .6565\end{array}$ & $\begin{array}{r}-1.15067 \\
-1.665+1\end{array}$ \\
\hline Constant & $\begin{array}{c}1.570700 " \\
\quad 1.5192\end{array}$ & $\begin{array}{c}2.52120 \\
1.6313\end{array}$ & $\begin{array}{r}1.60467 \\
\quad .5131\end{array}$ & $\begin{array}{c}2.57366 \\
\quad .61212\end{array}$ & $\begin{array}{c}0.87805 \ldots \\
\quad .231 !\end{array}$ & 1.39594 " & $\begin{array}{c}0.87528 \text {." } \\
\text {..2sus }\end{array}$ & $\begin{array}{c}1.36437 \ldots \\
., 313, \cdots\end{array}$ & $\begin{array}{r}-0.11224 \\
1.91912\end{array}$ & $\begin{array}{r}-0.03159 \\
\quad \text {..4.1!" }\end{array}$ & $\begin{array}{c}3.45903 \ldots \\
1.26 m+1\end{array}$ & $\begin{array}{c}0.06169 \\
\text { t.4.45? }\end{array}$ \\
\hline awm.... & 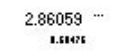 & $\begin{array}{l}2.79045 \\
\quad . .6135\end{array}$ & 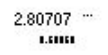 & $\begin{array}{c}2.71150 \ldots \\
\quad . .6711\end{array}$ & 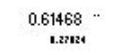 & $\begin{array}{c}0.65633 \\
0.19+12\end{array}$ & $\begin{array}{c}0.61965 \\
\text {..27r6! }\end{array}$ & 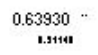 & $\begin{array}{r}0.37502 \\
\quad .9323\end{array}$ & $\begin{array}{r}0.59994 \\
\text { W.4313 }\end{array}$ & $\begin{array}{r}-0.15899 \\
\mathbf{L} .41766\end{array}$ & $\begin{array}{r}0.19757 \\
\quad . .531\end{array}$ \\
\hline R.ra & 0.684 & 0.669 & 0.685 & 0.667 & $0.5 \% 5$ & 0.463 & 0.584 & 0.464 & 0.798 & 0.781 & $0.7 \%$ & 0.714 \\
\hline samplesizo & 112 & 112 & 112 & 112 & 72 & 72 & 72 & 72 & 90 & 90 & 90 & 40 \\
\hline
\end{tabular}

Noves: The regression periods for Malaysia and Thailand are 1998-2005 and 1998-2006, respectively. $\because "$, and "' indicate that the statistics are significant at the $10 \%, 5 \%$, and $1 \%$ level, respectively. The dependent variable is the ratio of NPLs to total loans (for bank i and period $t$. The

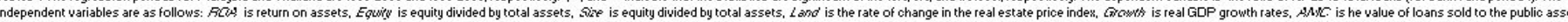
management company by each bank divided by total assets. Tum and $\square$ is a 0 - 1 dummy variable taking a value of one in the period without the purchase of NPLs by asset management companies and 0 otherwise. The dummy periods in the regressions for Malaysia and Thailand are
$2001-05$ and $1998-2000$, respectively. 
Table 6: Determinants of nonperforming loan ratios: the dynamic panel regression

\begin{tabular}{|c|c|c|c|c|c|c|c|c|c|c|c|c|}
\hline & Malaysia (Comme & investment banks & & & Malaysia (Comme & & & & Thaland & & & \\
\hline $\begin{array}{r}\text { NPL lagged ratio } \\
\text { stlen. }\end{array}$ & $\begin{array}{c}0.391362 \cdots \\
0.09350\end{array}$ & $\begin{array}{c}0.396527 \cdots \\
0.07015\end{array}$ & $\begin{array}{c}0.440960 \\
0.091248\end{array}$ & $\begin{array}{c}0.435636 \cdots \\
0.073814\end{array}$ & $\begin{array}{c}0.953562 \cdots \\
0.121283\end{array}$ & $\begin{array}{c}0.468212 \cdots \\
0.110008\end{array}$ & $\begin{array}{c}0.939754 \cdots \\
0.112189\end{array}$ & $\begin{array}{c}0.530753 \\
0.006615\end{array}$ & $\begin{array}{c}0.314864 \cdots \\
0.066552\end{array}$ & $\begin{array}{c}0.282082 \cdots \\
0.073410\end{array}$ & $\begin{array}{c}0.334827 \cdots \\
0.002999\end{array}$ & $\begin{array}{c}0.361035 \cdots \\
0.081092\end{array}$ \\
\hline$R O A \underset{\text { stlex. }}{ }$ & $\begin{array}{r}0.002077 \\
0.00917\end{array}$ & & $\begin{array}{r}0.00403 \\
0.00913\end{array}$ & & $\begin{array}{c}-0.05233 \cdots \\
0.00533\end{array}$ & & $\begin{array}{c}-0.046668 \cdots \\
0.00221\end{array}$ & & $\begin{array}{c}-0.01006 " \\
0.00395\end{array}$ & & $\begin{array}{c}-0.01354 \cdots \\
0.0032\end{array}$ & \\
\hline $\begin{array}{l}\text { Equity } \\
\text { sthex. }\end{array}$ & & $\begin{array}{r}0.80683 \\
0.00019\end{array}$ & & $\begin{array}{r}0.94685 \\
0.59333\end{array}$ & & $\begin{array}{c}-1.47646 \cdots \\
03650\end{array}$ & & $\begin{array}{c}-1.31973 \quad \cdots \\
0.31817\end{array}$ & & $\begin{array}{r}-0.36944 \\
0.3093\end{array}$ & & $\begin{array}{r}-0.30521 \\
0.3734\end{array}$ \\
\hline $\begin{array}{l}\text { Size } \\
\text { sther. }\end{array}$ & $\begin{array}{c}-0.11768 \cdots \\
0.03924\end{array}$ & $\begin{array}{r}-0.06466 \\
0.09455\end{array}$ & $\begin{array}{l}-0.10137 \text { '." } \\
0.03675\end{array}$ & $\begin{array}{r}-0.04230 \\
0.04602\end{array}$ & $\begin{array}{c}-0.05011 " \\
0.0175\end{array}$ & $\begin{array}{c}-0.08126 \cdots \\
0.02275\end{array}$ & $\begin{array}{c}-0.04156 " \\
0.01641\end{array}$ & $\begin{array}{c}-0.06485 \cdots \\
0.01990\end{array}$ & $\begin{array}{r}-0.02660 \\
0.03873\end{array}$ & $\begin{array}{r}-0.02176 \\
0.03939\end{array}$ & $\begin{array}{r}-0.02814 \\
0.04063\end{array}$ & $\begin{array}{r}-0.02515 \\
0.04478\end{array}$ \\
\hline $\begin{array}{l}\text { Land } \\
\text { stier. }\end{array}$ & $\begin{array}{r}0.27004 \\
0.35433\end{array}$ & $\begin{array}{r}0.17772 \\
03487\end{array}$ & & & $\begin{array}{r}-0.11745 \\
0.16178\end{array}$ & $\begin{array}{r}-0.19829 \\
0.1878\end{array}$ & & & $\begin{array}{c}-0.549266^{\circ} \\
0.31929\end{array}$ & $\begin{array}{c}-1.13751 \cdots \\
0.22126\end{array}$ & & \\
\hline $\begin{array}{l}\text { Growth } \\
\text { stlerr. }\end{array}$ & & & $\begin{array}{r}-0.14450 \\
020589\end{array}$ & $\begin{array}{r}-0.18409 \\
0.1987\end{array}$ & & & $\begin{array}{c}-0.19397 \% \\
0.00638\end{array}$ & $\begin{array}{c}-0.30465 \cdots \\
0.07240\end{array}$ & & & $\begin{array}{r}-0.38952 \\
0.41414\end{array}$ & $\begin{array}{c}-1.27990 \cdots \\
0.41847\end{array}$ \\
\hline$A M C$ & $\begin{array}{r}-0.56418 \\
033356\end{array}$ & $\begin{array}{c}-0.48080^{\circ} \\
029023\end{array}$ & $\begin{array}{r}-0.45766 \\
039887\end{array}$ & $\begin{array}{r}-0.39359 \\
0.29920\end{array}$ & $\begin{array}{r}-1.57149 \\
1.23346\end{array}$ & $\begin{array}{c}-3.25216 \cdots \\
123057\end{array}$ & $\begin{array}{r}-1.17676 \\
0.84788\end{array}$ & $\begin{array}{c}-2.36700 \cdots \\
0.84832\end{array}$ & $\begin{array}{c}-1.36702 " \\
0.5625\end{array}$ & $\begin{array}{c}-2.16503 \\
0.6261\end{array}$ & $\begin{array}{c}-1.16562 " \\
0.5739\end{array}$ & $\begin{array}{c}-1.87667 \cdots \\
0.7027\end{array}$ \\
\hline $\begin{array}{l}\text { Constant } \\
\text { stider. }\end{array}$ & $\begin{array}{c}2.93849 \cdots \\
093228\end{array}$ & $\begin{array}{r}1.60407 \\
121516\end{array}$ & $\begin{array}{c}2.55040 \cdots \\
087091\end{array}$ & $\begin{array}{r}1.06429 \\
1.12922\end{array}$ & $\begin{array}{c}1.27758 \cdots \\
0.43619\end{array}$ & $\begin{array}{c}2.18748 \cdots \\
0.57103\end{array}$ & $\begin{array}{c}1.07570 \cdots \\
0.4019\end{array}$ & $\begin{array}{c}1.78032 \\
0.49930\end{array}$ & $\begin{array}{r}0.81507 \\
1.00993\end{array}$ & $\begin{array}{r}0.72965 \\
1.04892\end{array}$ & $\begin{array}{r}0.87036 \\
1.08743\end{array}$ & $\begin{array}{r}0.85639 \\
1.9237\end{array}$ \\
\hline $\begin{array}{l}\text { Sargan test tstatistic } \\
\text { Number of observation }\end{array}$ & $\begin{array}{l}92.792 . " \\
\quad 84\end{array}$ & $\begin{array}{c}97.839 \cdots \\
84\end{array}$ & $\begin{array}{c}94927 \cdots \\
\quad 84\end{array}$ & $\begin{array}{l}99991 \cdots \\
\quad 84\end{array}$ & $\begin{array}{r}45.718 \\
54\end{array}$ & $\begin{array}{r}55.651 \\
54\end{array}$ & $\begin{array}{r}46.160 \\
54\end{array}$ & $\begin{array}{r}51.521 \\
54\end{array}$ & $\begin{array}{r}46.536 \\
70\end{array}$ & $\begin{array}{r}50.824 \\
70\end{array}$ & $\begin{array}{r}44.167 \\
70\end{array}$ & $\begin{array}{r}50389 \\
70\end{array}$ \\
\hline
\end{tabular}

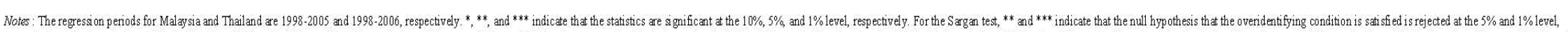

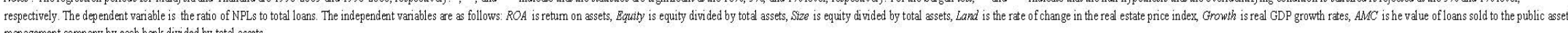
management comp any by each bank divided by total assets 
Table 7: Determinants of nonperforming loan ratios: the dynamic panel regression with dummies

\begin{tabular}{|c|c|c|c|c|c|c|c|c|c|c|c|c|}
\hline & Malaysia (Com & and investm & & & Malaysia [Cor & al banks] & & & Thailand & & & \\
\hline 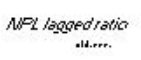 & $\begin{array}{l}0.132598 \\
\quad \text {...⿲丿丨 }\end{array}$ & $\begin{array}{c}0.161146 \\
\text {..915: }\end{array}$ & $\begin{array}{l}0.114689 \\
\text {.1.1123r? }\end{array}$ & $\begin{array}{l}0.116450 \\
1.1+31\end{array}$ & $\begin{array}{c}0.723044 \\
\text { (1.w34, }\end{array}$ & $\begin{array}{c}0.209282 \\
\text { 1.4145s " }\end{array}$ & 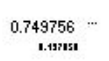 & $\begin{array}{c}0.255843 \\
\text { L.t1139; }\end{array}$ & $\begin{array}{c}0.283640 \ldots \\
\quad . .135+16\end{array}$ & 0.255887 & $0.295551 \ldots$ & $0.271414 \ldots$ \\
\hline$A C O_{1}$ & $\begin{array}{r}-0.00845 \\
. . .1+1,\end{array}$ & & $\begin{array}{r}-0.00755 \\
. . .193 s\end{array}$ & & $\begin{array}{c}.0 .04106 \\
. .11789\end{array}$ & & $\begin{array}{c}-0.03832 \ldots \\
. .113, \cdots\end{array}$ & & $\begin{array}{c}-0.00949 \cdots " \\
. .1 .9 \%\end{array}$ & & 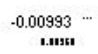 & \\
\hline aras & $\begin{array}{l}4.14107 \ldots \\
\text {..sus! }\end{array}$ & & $\begin{array}{l}4.08791 \ldots \\
\text {...su" }\end{array}$ & & 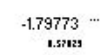 & & $\begin{array}{l}-1.56284, \cdots \\
.5 s+3\end{array}$ & & $\begin{array}{r}0.00081 \\
. . .13\end{array}$ & & $\begin{array}{c}0.00093 \\
. . .193 \\
\end{array}$ & \\
\hline Equity & & $\begin{array}{r}0.33099 \\
\mathbf{1 . 6 4 2 1 2}\end{array}$ & & $\begin{array}{l}0.11719 \\
\text { D.746st }\end{array}$ & & $\underset{1.2051}{-2.0235}$ & & $\begin{array}{c}-1.94557 \\
. ., 313\end{array}$ & & $\begin{array}{r}-0.13778 \\
. .34+1\end{array}$ & & $\begin{array}{r}-0.23398 \\
., 931 !\end{array}$ \\
\hline GEquity & & $\begin{array}{r}0.37390 \\
\quad 1.56531\end{array}$ & & $\begin{array}{r}0.29523 \\
1.52314\end{array}$ & & $\begin{array}{r}0.00464 \\
\text {..1467 }\end{array}$ & & $\begin{array}{r}0.07547 \\
. .2119\end{array}$ & & 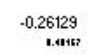 & & $\begin{array}{r}-0.28880 \\
\text {...tuta }\end{array}$ \\
\hline Sire & $\begin{array}{l}-0.25160 \cdots \cdots \\
-. .193 r\end{array}$ & 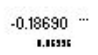 & $\begin{array}{c}-0.25992 \cdots \\
0.0435 \%\end{array}$ & $\underset{0.0877762}{-0.2177}$ & $\begin{array}{c}-0.06342 \ldots \\
. .13255\end{array}$ & $\begin{array}{l}-0.16208 \\
. .1 .2235\end{array}$ & $\begin{array}{r}-0.03643 \\
0.02615\end{array}$ & $\begin{array}{c}-0.14955 \ldots \\
0.03423\end{array}$ & $\begin{array}{c}-0.01794 \\
0.04228\end{array}$ & $\begin{array}{r}-0.02429 \\
0.04291\end{array}$ & $\begin{array}{r}-0.02366 \\
0.04411\end{array}$ & $\begin{array}{c}-0.03639 \\
0.04161\end{array}$ \\
\hline axpe & $\begin{array}{c}-0.05127 \ldots \\
., 14312\end{array}$ & $\begin{array}{r}-0.02966 \\
.1 .12122\end{array}$ & $\begin{array}{c}-0.05340 \cdots \\
0.01654\end{array}$ & $\begin{array}{c}-0.03281 \\
0.02156\end{array}$ & $\begin{array}{c}-0.01635 \\
.0 .1151\end{array}$ & $\begin{array}{c}-0.02988 \\
\text {....." }\end{array}$ & $\begin{array}{r}-0.00992 \\
0.01049\end{array}$ & $\begin{array}{c}-0.02679 \cdots \\
0.01039\end{array}$ & $\begin{array}{r}-0.00028 \\
0.01121\end{array}$ & $\begin{array}{r}0.00280 \\
0.01215\end{array}$ & $\begin{array}{r}-0.00009 \\
0.01131\end{array}$ & $\begin{array}{r}0.00449 \\
0.01222\end{array}$ \\
\hline Land & $\begin{array}{c}0.31294 \\
0.27307\end{array}$ & $\begin{array}{l}0.33686 \\
0.354\end{array}$ & & & $\begin{array}{c}0.10706 \\
0.16644\end{array}$ & 0.09207 & & & $\begin{array}{l}-0.32772 \\
. \quad .6354\end{array}$ & $\begin{array}{r}-0.63529 \\
.02354\end{array}$ & & \\
\hline arand & $\begin{array}{l}-1.36109 \cdots \\
0.57770\end{array}$ & $\begin{array}{c}-1.34284 \text {. } \\
\text {..67we }\end{array}$ & & & $\begin{array}{r}0.24600 \\
0.27524\end{array}$ & $\begin{array}{r}-0.38398 \\
. .2444\end{array}$ & & & $\begin{array}{r}0.85852 \\
2.1 .113\end{array}$ & $\begin{array}{r}1.54836 \\
2.4921\end{array}$ & & \\
\hline Ancowts. & & & $\begin{array}{r}0.31334 \\
1.22155\end{array}$ & $\begin{array}{c}0.38515 \\
\text {...m!n }\end{array}$ & & & $\begin{array}{r}-0.18456 \\
\text { t.1135s }\end{array}$ & $\begin{array}{r}-0.02070 \\
\text {..14t6s, }\end{array}$ & & & $\begin{array}{r}-0.01310 \\
-1.4165\end{array}$ & $\begin{array}{c}0.01468 \\
1.51271\end{array}$ \\
\hline 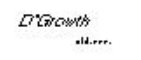 & & & $\underset{.0 .22114}{.1533}$ & $\begin{array}{l}-0.216999 \\
\text { t.ansss }\end{array}$ & & & $\begin{array}{r}-0.02029 \\
. .1315\end{array}$ & $\begin{array}{r}-0.09848 \\
. .1934\end{array}$ & & & $\begin{array}{l}-1.08321 \\
1.211\end{array}$ & $\begin{array}{l}-2.15858 \\
\text {..6184, }\end{array}$ \\
\hline AMC. & $\begin{array}{r}-0.43197 \\
. .1311\end{array}$ & $\begin{array}{r}-0.22293 \\
.1 .914\end{array}$ & $\begin{array}{r}-0.41484 \\
\text {..a114 }\end{array}$ & $\begin{array}{r}-0.25546 \\
. .41393\end{array}$ & $\begin{array}{r}0.22360 \\
1.2315\end{array}$ & $\begin{array}{r}-0.81208 \\
\text { 1.1.20: }\end{array}$ & $\begin{array}{r}-1.03570 \\
.1 .31 ! 1\end{array}$ & $\begin{array}{r}-1.23843 \\
\text { t.Mukz }\end{array}$ & 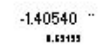 & $\begin{array}{c}-1.63790 \\
.602 n\end{array}$ & $\begin{array}{c}-1.37580 \cdots \\
. .654\end{array}$ & $\begin{array}{c}-1.65572, " \\
\quad . .62 s\end{array}$ \\
\hline Constant & $\begin{array}{c}6.07573 \ldots \\
\text { t.s354 }\end{array}$ & $\begin{array}{l}4.51361 \cdots \\
1.6931\end{array}$ & $\begin{array}{l}6.24613 \cdots \\
\text { 1.rans }\end{array}$ & $\begin{array}{c}5.23393 \\
2.11211\end{array}$ & 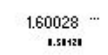 & $\begin{array}{l}4.18824 \ldots \\
. .56 a 1\end{array}$ & $\begin{array}{r}0.96439 \\
., 51393\end{array}$ & $\begin{array}{c}3.87730 \ldots \\
\quad \text {...4s }\end{array}$ & $\begin{array}{r}0.58715 \\
1.12615\end{array}$ & $\begin{array}{r}0.76807 \\
1.446,9\end{array}$ & $\begin{array}{r}0.73670 \\
1.19 \%\end{array}$ & $\begin{array}{r}1.09328 \\
1.11111\end{array}$ \\
\hline Rams & $\begin{array}{c}1.34361 \ldots \\
. .3 r \cdots\end{array}$ & $\begin{array}{l}0.80193 \\
., 5342\end{array}$ & $\begin{array}{c}1.39758 \cdots \\
\quad . .31 !\end{array}$ & ${ }_{1.8435}^{0.89753}$ & $\begin{array}{c}0.43566 \\
. .339\end{array}$ & 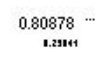 & $\begin{array}{r}0.26105 \\
. .645 s\end{array}$ & $\begin{array}{l}0.71771 \ldots \\
\text { L.susts }\end{array}$ & $\begin{array}{r}0.10963 \\
.1 .1313\end{array}$ & $\begin{array}{c}0.11988 \\
\quad .1 .54 m\end{array}$ & $\begin{array}{r}0.00679 \\
1.3424\end{array}$ & $\begin{array}{c}-0.10279 \\
1 ., 3 m\end{array}$ \\
\hline 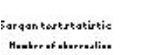 & $\begin{array}{c}90.012 \cdots \\
\$ 4\end{array}$ & $\$ \$ \$ .674 \ldots$ & $\begin{array}{l}90.093 \\
\$ 4\end{array}$ & $\$ 83.399, \ldots$ & $\begin{array}{l}38.987 \\
54\end{array}$ & $\begin{array}{c}59.191 . \\
54\end{array}$ & $\begin{array}{l}39.616 \\
54\end{array}$ & ${ }_{56.641} \cdot$ & $\begin{array}{l}53.410 \\
70\end{array}$ & $\begin{array}{l}57.281 \\
70\end{array}$ & $\begin{array}{r}53.029 \\
70\end{array}$ & $\begin{array}{r}56.3822 \\
70\end{array}$ \\
\hline
\end{tabular}

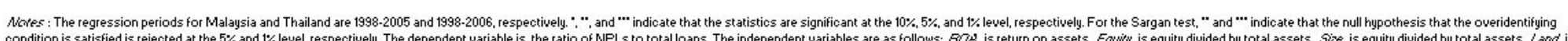
condition is satisfied is rejected at the $5 \%$ and $1 \%$ level, respectively. The dependent variable is the ratio of NPL 5 to total loans. The independent variables are as follows: FCOS is return on assets, Equity is equity divided by total assets, Sire is equity divided by total assets, Land is the

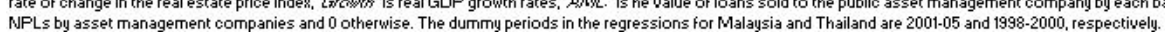




\section{Table 8: Determinants of the rate changes of loans}

\begin{tabular}{|c|c|c|c|c|c|c|c|c|c|c|c|c|}
\hline \multirow[b]{2}{*}{$\begin{array}{l}50, \text { int } \\
\text { red.ert. }\end{array}$} & \multicolumn{4}{|c|}{ Malaysia [Commercial and investment banks] } & \multicolumn{4}{|c|}{ Malaysia (Commercial banks) } & \multicolumn{4}{|l|}{ Thailand } \\
\hline & $\begin{array}{c}3.343533 \\
1.54846\end{array}$ & & $\begin{array}{c}3.16352 \text { " } \\
1.53841\end{array}$ & & $\begin{array}{r}4.34336 \\
2.367833\end{array}$ & & $\begin{array}{r}3.67271 \\
2.967772\end{array}$ & & $\begin{array}{c}-0.04865 \\
0.01361\end{array}$ & & $\begin{array}{c}-0.02943 \\
0.01190\end{array}$ & \\
\hline 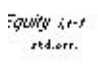 & & $\begin{array}{r}-0.39153 \\
1.161118\end{array}$ & & $\begin{array}{r}-0.45699 \\
1.10719\end{array}$ & & $\underset{1.008836}{2.90061}$ & & $\begin{array}{c}2.83896 \\
0.99793\end{array}$ & & $\begin{array}{r}2.74800 \\
1.45633\end{array}$ & & $\begin{array}{r}2.57279 \\
1.47120\end{array}$ \\
\hline $\begin{array}{l}\text { Sine int } \\
\text { rtd.err. }\end{array}$ & $\frac{-0.12618}{0.05608}$ & $\begin{array}{r}-0.13876 \\
0.07702\end{array}$ & $\begin{array}{c}-0.13465 \\
0.05256\end{array}$ & $\begin{array}{c}-0.14232 \\
0.06863\end{array}$ & $\begin{array}{c}-0.05780 \\
0.02866\end{array}$ & $\begin{array}{r}-0.04412 \\
0.02726\end{array}$ & $\begin{array}{c}-0.05790 \\
0.02796\end{array}$ & $\underset{-0.04364}{0.02643}$ & $\begin{array}{c}-0.43619 \\
0.17939\end{array}$ & $\begin{array}{c}-0.91948 \\
0.21325\end{array}$ & $\begin{array}{c}-0.58107 \\
0.19011\end{array}$ & $\begin{array}{c}-0.94793 \\
0.21533\end{array}$ \\
\hline $\begin{array}{l}\text { Land tr-t } \\
\text { ret.err. }\end{array}$ & $\begin{array}{r}-0.04850 \\
0.34693\end{array}$ & $\begin{array}{c}0.14407 \\
0.37249\end{array}$ & & & $\begin{array}{r}0.07401 \\
0.41232\end{array}$ & $\begin{array}{r}0.28082 \\
0.38682\end{array}$ & & & $\begin{array}{c}4.80824 \\
1.26303\end{array}$ & $\begin{array}{r}1.67270 \\
1.06666\end{array}$ & & \\
\hline 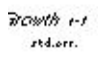 & & & $\begin{array}{c}0.17337 \\
0.31752\end{array}$ & $\begin{array}{c}0.30943 \\
0.32761\end{array}$ & & & $\begin{array}{r}0.30295 \\
0.39452\end{array}$ & $\begin{array}{r}0.45878 \\
0.35396\end{array}$ & & & $\begin{array}{c}2.95249 \\
1.00627\end{array}$ & $\frac{1.64535}{0.98168}$ \\
\hline $\begin{array}{l}\text { NMC int } \\
\text { std.err. }\end{array}$ & $\begin{array}{c}1.22323 " \\
0.49097\end{array}$ & $\begin{array}{r}0.79179 \\
0.45799\end{array}$ & $\begin{array}{c}1.19256 " \\
0.49221\end{array}$ & $\begin{array}{c}0.77053 \\
0.45543\end{array}$ & $\begin{array}{l}8.63529 \cdots \\
1.55104\end{array}$ & $\begin{array}{l}8.46100 \cdots \\
1.48991\end{array}$ & $\begin{array}{c}8.77629 \cdots \\
1.48188\end{array}$ & $\begin{array}{c}8.48249 \cdots \\
1.42023\end{array}$ & $\begin{array}{r}-1.44988 \\
2.79696\end{array}$ & $\begin{array}{r}-1.36738 \\
3.09708\end{array}$ & $\begin{array}{r}-2.46078 \\
2.89699\end{array}$ & $\begin{array}{r}-1.73400 \\
3.12557\end{array}$ \\
\hline $\begin{array}{c}\text { constant } \\
\text { rtacert. }\end{array}$ & $\begin{array}{c}2.96539 \\
1.31976\end{array}$ & $\begin{array}{r}3.32618 \\
1.39246\end{array}$ & $\begin{array}{l}3.15774 \text {." } \\
1.23115\end{array}$ & $\begin{array}{c}3.39949 \cdot- \\
1.680080\end{array}$ & $\begin{array}{l}1.46164 . " \\
0.69344\end{array}$ & $\begin{array}{c}0.91554 \\
0.67579\end{array}$ & $\begin{array}{c}1.45298 \\
0.67412\end{array}$ & $\begin{array}{r}0.88273 \\
0.65441\end{array}$ & $\begin{array}{c}11.63582 \\
4.74775\end{array}$ & $\begin{array}{r}24.19841 \ldots \\
5.56912\end{array}$ & $\begin{array}{c}15.37033 \ldots \\
5.02714\end{array}$ & $\begin{array}{c}24.91422 \cdots \\
5.622 * 3\end{array}$ \\
\hline R.r4 & 0.131 & 0.089 & 0.133 & 0.096 & 0.384 & 0.433 & 0.390 & 0.443 & 0.336 & 0.259 & 0.290 & \\
\hline ramples rizo & 112 & 112 & 112 & 112 & 72 & 72 & 72 & 72 & 90 & 90 & 90 & 90 \\
\hline
\end{tabular}

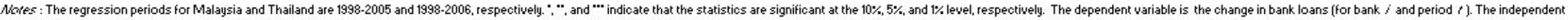

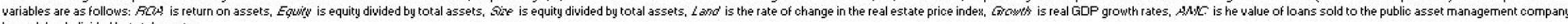
by each bank divided by total assets. 


\section{Previous Asia Pacific Economic Papers}

397 Global Production Sharing and the FDI-Trade Nexus: New Evidence from the Japanese Automobile Industry Shuhei Nishitateno, 2012

396 Changes in the Labour Supply of Japanese Women between 1993 and 2008: A Panel Data Analysis Tomoko Kishi, 2012

395 Will Fertility Rebound in Japan? Creina Day, 2012

394 Stock prices of domestic banking sector and external shocks in east Asia Masahiro Inoguchi, 2011

393 Tax Consolidation and the Structure of Corporate Groups: Evidence from the Japanese Tax Reform 2002 Kazuki Onji, 2011

392 The reform of public health insurance and economic growth of Japan Toshihiro Ihori, Ryuta Ray Kato, Masumi Kawade, Shun-ichiro Bessho, 2011

391 Negative impacts of capital injection policies on the capital crunch: evidence from Japan Takeshi Osada, 2011

390 Capital Injection, Restructuring Targets and Personnel Management: The Case of Japanese Regional Banks Kazuki Onji, David Vera, Jenny Corbett, 2011

389 Beyond 'Asian Values': Rationales for Australian-Japan Cooperation in Asian Regionalism Go Ito, 2010

388 How Does a Decrease in Oil Production Affect the World Economy? Naohiko Yahaba, 2010

387 Internal Promotion and the Effect of Board Monitoring: a Comparison of Japan and the United States Meg Sato, 2010

386 Interaction between trade, conflict and cooperation: the case of Japan and China Shiro Armstrong, 2010

385 Japanese Aid as a prerequisite for FDI: the case of Southeast Asian countries Séverine Blaise, 2009

384 Insular Decision-making in the Board Room: Why Boards Retain and Hire Sub-Standard CEOs Meg Sato, 2009

383 How does Financial System Efficiency Affect the Growth Impact of FDI in China? Ying Xu, 2009

382 A Tale of Pork Prices: Evasion and Attenuation of a Japanese Tariff Kazuki Onji, 2009

381 Are the East Asian Currencies Still Misaligned? An Analysis Based on Absolute ppp-Income Relationship using Panel Data

Taizo Motonishi, 2009

380 Is Foreign Aid a Vanguard of Foreign Direct Investment? A Gravity-Equation Approach Hidemi Kimura and Yasuyuki Todo, 2009 
Annual subscription rate for up to eight issues:

Individuals $A \$ 65.00$ (includes GST) $A \$ 60$ (overseas)

Institutions $A \$ 110.00$ (includes GST) $A \$ 100$ (overseas)

Cost for single issues:

$\mathrm{A} \$ 16.50$ (includes GST) $\mathrm{A} \$ 15.00$ (overseas)

$\mathrm{A} \$ 10.00$ (Students)

No postage required within Australia

Available from:

\section{Centre Administrator}

Australia-Japan Research Centre

Crawford School of Public Policy

ANU College of Asia and the Pacific

The Australian National University

Canberra ACT 0200, Australia

Facsimile: (61 2) 61258448

Telephone: (61 2) 61250168

Email:_ajrc@anu.edu.au

URL: http://www.crawford.anu.edu.au/research_units/ajrc/ 